Document downloaded from:

http://hdl.handle.net/10251/33333

This paper must be cited as:

Garófano-Gómez, V., F. Martínez-Capel, W. Bertoldi, A. Gurnell, J. Estornell, F. SeguraBeltrán (2012). Six decades of changes in the riparian corridor of a Mediterranean river: A synthetic analysis based on historical data sources. Ecohydrology, 6 (4): 536 ¿553. doi:10.1002/eco.1330.

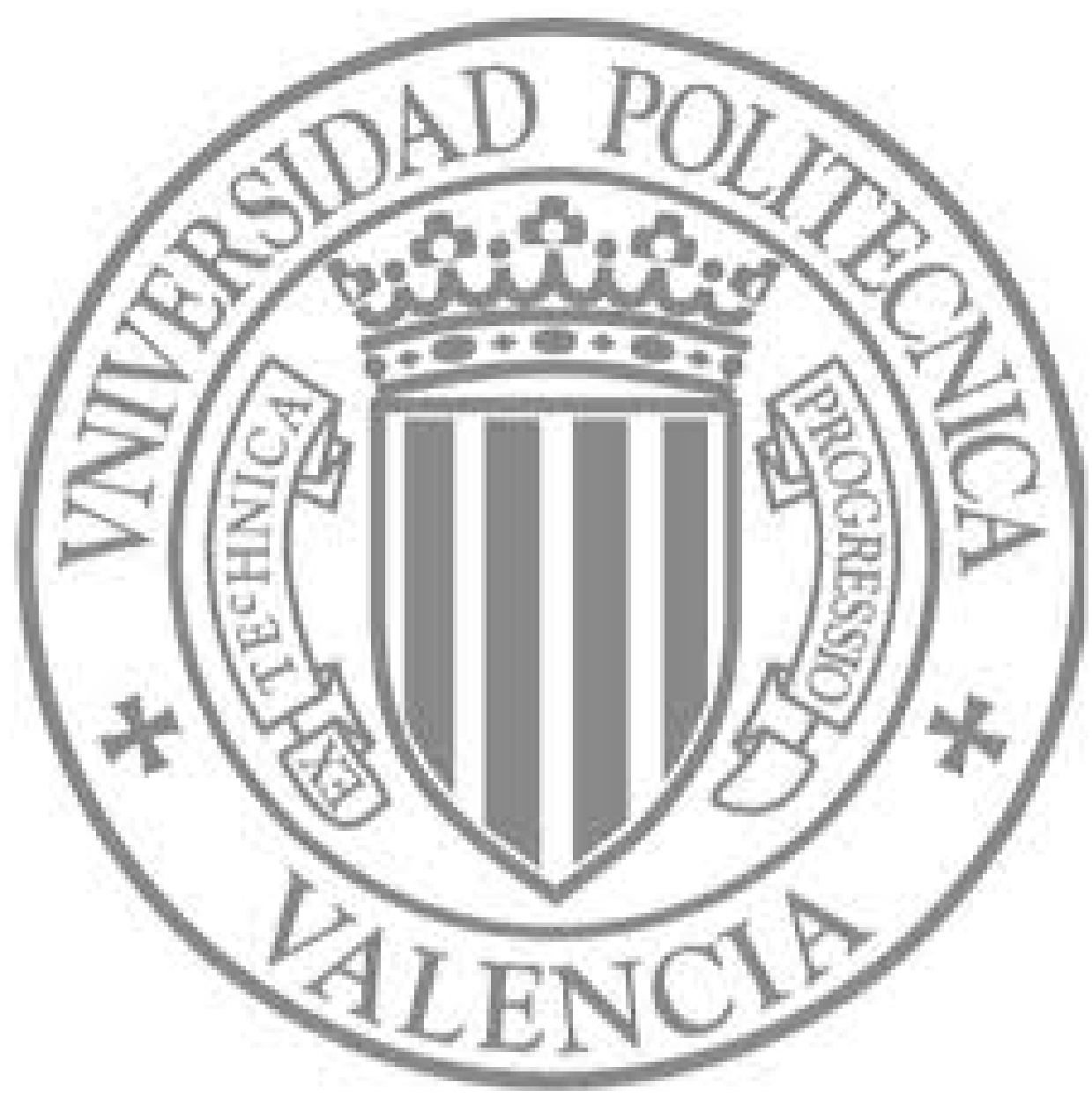

The final publication is available at

http://doi.wiley.com/10.1002/eco.1330

Copyright Wiley-Blackwell 
This is a pre-copyedited, author-produced PDF version following peer review of the article: GarófanoGómez, V., F. Martínez-Capel, W. Bertoldi, A. Gurnell, J. Estornell, F. Segura-Beltrán. 2013. Six decades of changes in the riparian corridor of a Mediterranean river: A synthetic analysis based on historical data sources. Ecohydrology, 6 (4): 536-553, which has been published in definitive publisher-authenticated form at http://onlinelibrary.wiley.com/doi/10.1002/eco.1330/abstract Article first published online: 4 OCT 2012 by John Wiley \& Sons, Ltd. All rights reserved. All further use of this material other than for personal research is subject to permission from the publisher.

\title{
SIX DECADES OF CHANGES IN THE RIPARIAN CORRIDOR OF A MEDITERRANEAN RIVER: A SYNTHETIC ANALYSIS BASED ON HISTORICAL DATA SOURCES
}

\author{
V. Garófano-Gómez, ${ }^{1 *}$ F. Martínez-Capel, ${ }^{1}$ W. Bertoldi, ${ }^{2}$ A. Gurnell, ${ }^{3}$ J. Estornell ${ }^{4}$ and F. Segura-Beltrán ${ }^{5}$
}

\footnotetext{
${ }^{1}$ Research Institute for Integrated Management of Coastal Areas, Universitat Politècnica de València, Grao de Gandia, València, Spain

${ }^{2}$ Department of Civil and Environmental Engineering, University of Trento, Trento, Italy

${ }^{3}$ School of Geography, Queen Mary, University of London, London, UK

${ }^{4}$ Grupo de Investigación de Cartografía GeoAmbiental y Teledetección, Universitat Politècnica de València, València, Spain

${ }^{5}$ Departament de Geografia, Facultat de Geografia i Història, Universitat de València, València, Spain

*Correspondence to: virginiagarofano@gmail.com
}

\begin{abstract}
Riparian corridors in semi-arid Mediterranean environments are ecosystems of high biodiversity and complexity. However, they are threatened because of high levels of human intervention. River damming and related flow manipulation is considered as one of the most prominent human impacts on riparian corridors. This study combines historical time series information on river flows and their human manipulation, historical aerial images depicting changes in riparian land cover and ground observations of the species - age composition and morphology of the riparian corridor of a Mediterranean river (the Mijares River, Eastern Spain) over the last 60 years. In this sense, we explored how to integrate information from a wide variety of data sources, and we extracted a variety of indices and undertook analyses that identified and summarized spatio-temporal changes in riparian structure and in the driving flow processes. Results revealed an increase in the cover and density of woody vegetation and a decrease in bare sediment areas (essential for recruitment of riparian pioneer species), with a synchronous reduction in the complexity of the riparian corridor of the middle reaches of the Mijares River. These vegetation changes have accompanied a decrease in the magnitude and variability of river flows over the last six decades, with higher severity since dam closure. This study illustrates the effectiveness of combining disparate historical data sources and the effectiveness of processing these sources to extract informative metrics that can improve the understanding and management of riparian systems.
\end{abstract}

\section{KEY WORDS}

Riparian vegetation; flow regulation; semi-arid Mediterranean river; temporal evolution; landscape metrics

\section{INTRODUCTION}

Riparian ecosystems have unique biodiversity and complexity (Naiman et al., 1993; Naiman et al., 2005), and they provide numerous benefits, such as food sources, ecological corridor, habitat and refugia for fauna, bank stabilization, improvement of water quality, temperature control and recreational value (Gregory et al., 1991; Schuft et al., 1999). However, riparian ecosystems are highly sensitive to disturbance and anthropogenic influences, and despite their value, they are threatened, especially in semi-arid Mediterranean environments (Salinas et al., 2000). Historically, Iberian Mediterranean-type streams have been subject to high levels of human intervention including intensive agriculture and forestry, water abstraction, damming, 
grazing, mining, physical interventions on riverbanks and urban development (Aguiar and Ferreira, 2005; Hooke, 2006). Among all these human impacts, river damming and related flow manipulation is one of the most prominent (Naiman et al., 2005; Petts and Gurnell, 2005; Petts and Gurnell, 2012), with significant negative consequences for the surrounding natural ecosystems and environment (New and Xie, 2008).

Depending on the degree of water regulation, changes in the quantity, timing and variability of downstream water flow may occur (Greet et al., 2011), accompanied by changes in sediment transport and in the configuration of the riparian and wetland habitats ( $\operatorname{Rood}$ et al., 2005), resulting in a fragmentation of the river channel and its biotic populations (Dynesius and Nilsson, 1994). According to Katz et al. (2005), in the North American Great Plains, dams typically have reduced both downstream peak discharge and sediment load, resulting in diminished stream power downstream and a narrower active river channel. When dams retain sediment and reduce discharge, in the long term, there is a reduction in the channel migration rate because those flows able to produce erosion and point bar deposition are no longer released (Friedman et al., 1998; Johnson, 1998). In addition to this, in many Mediterranean rivers, gravel mining was carried out below the dams, combining the effects of both impacts (mining and flow regulation) to produce an even larger sediment deficit (Batalla et al., 2004; Kondolf and Batalla, 2005). In Spain, in particular, gravel mining has been a common practice in rivers whose aggregates have been used in, for example, road and building construction.

The reduction in fluvial dynamism can provoke a reduction in the availability of bare sediment establishment sites for pioneer species (Rood and Mahoney, 1990) and, hence, a decline of riparian forests on regulated reaches. Numerous references about this decline in semi-arid North American rivers have been reported since the 1980s (e.g. Groeneveld and Griepentrog, 1985; Howe and Knopf, 1991; Busch and Smith, 1995; Stromberg et al., 1996; Patten, 1998; Williams and Cooper, 2005) and also more recently in the context of Mediterranean basins (Muller et al., 2002; González et al., 2010; González et al., 2012). In many cases, this decline is preceded by a significant increment in riparian biomass (Johnson, 1994), although this new vegetation may be composed of exotic woody species (Johnson et al., 1995; Dixon and Johnson, 1999). According to Azami et al. (2004), the degree of woodland development depends on the relationship between the timing of flood events and the rate of vegetative growth in the riparian zone.

Schuft et al. (1999) emphasized that the fragmentation and loss of complexity of riparian woodland reduce the efficient functioning of these ecosystems. In this sense, the management of riparian ecosystems, especially those in a Mediterranean climate, should take account of the importance of natural dynamism for maintenance of their biodiversity and ecological benefits (Ollero, 2007). It is, therefore, unsurprising that there is an increasing management interest in assessing the current integrity of the riparian corridor and the ways in which it may have changed through time (e.g. Aguiar et al., 2010; Garófano-Gómez et al., 2011; González del Tánago and García de Jalón, 2011).

The achievement of such assessments requires long-term observations (Nakamura and Shin, 2001). Although purpose specific long-term observations are rarely available, sequences of aerial images of widely varying spatial resolution (obtained from airborne and satellite platforms) provide historical records that can be used to evaluate river channel and corridor dynamics (e.g. Bertoldi et al., 2011a; Bertoldi et al., 2011b). The analysis of such sequences of historical imagery provides an opportunity to quantify large-scale features at a landscape scale and extract a variety of integrative metrics (Apan et al., 2002; Fernandes et al., 2011). Nevertheless, aerial images are insufficient to reveal small-scale features (local-level approach), such as plant species and community types (Braatne et al., 2008; Aguiar et al., 2010). Therefore, ground-level images, field surveys and data collection in situ are usually necessary to provide this detailed information as well as provide information from which interpretations of aerial data can be validated (e.g. Bertoldi et al., 2011b).

This study combines historical time series information on river flows and their human manipulation, historical aerial images depicting changes in riparian land cover and ground observations of the age composition and morphology of woody species of the riparian corridor of a Mediterranean river, the Mijares River, Eastern Spain, over the last 60 years. The aim of this study is to quantify changes in river flow regime, river channel position and width and riparian land cover within two naturally functioning alluvial reaches of the river and to explore associations between them. To achieve this, we make the following specific research contributions:

(i) We integrate information from a wide variety of data sources including process time series, airborne imagery of contrasting spatial resolution and transect-based ground data. 
(ii) We extract a variety of indices that summarize spatiotemporal changes in riparian structure and temporal changes in the driving flow processes.

(iii) Thus, we illustrate the effectiveness of combining disparate historical data sources and the effectiveness of processing these sources to extract informative metrics that can improve the understanding and management of riparian systems.

\section{STUDY AREA AND SITES}

The Mijares River rises at 1600mabove sea level in the Sierra de Gúdar (Teruel) and flows $156 \mathrm{~km}$ in a south-easterly direction to the Mediterranean Sea (Figure 1). Average annual rainfall and potential evapotranspiration in the basin are 550 and $722 \mathrm{~mm}$, respectively (Quereda et al., 2004), with maximum monthly rainfall typically occurring in October and minimum monthly rainfall in July (MOPREDAS database; González-Hidalgo et al., 2011). The river's natural flow regime has an important groundwater component but is also irregular, with extremely low flows in summer; extraordinary floods in autumn, in response to heavy rain storms; and further variability resulting from snow melt.

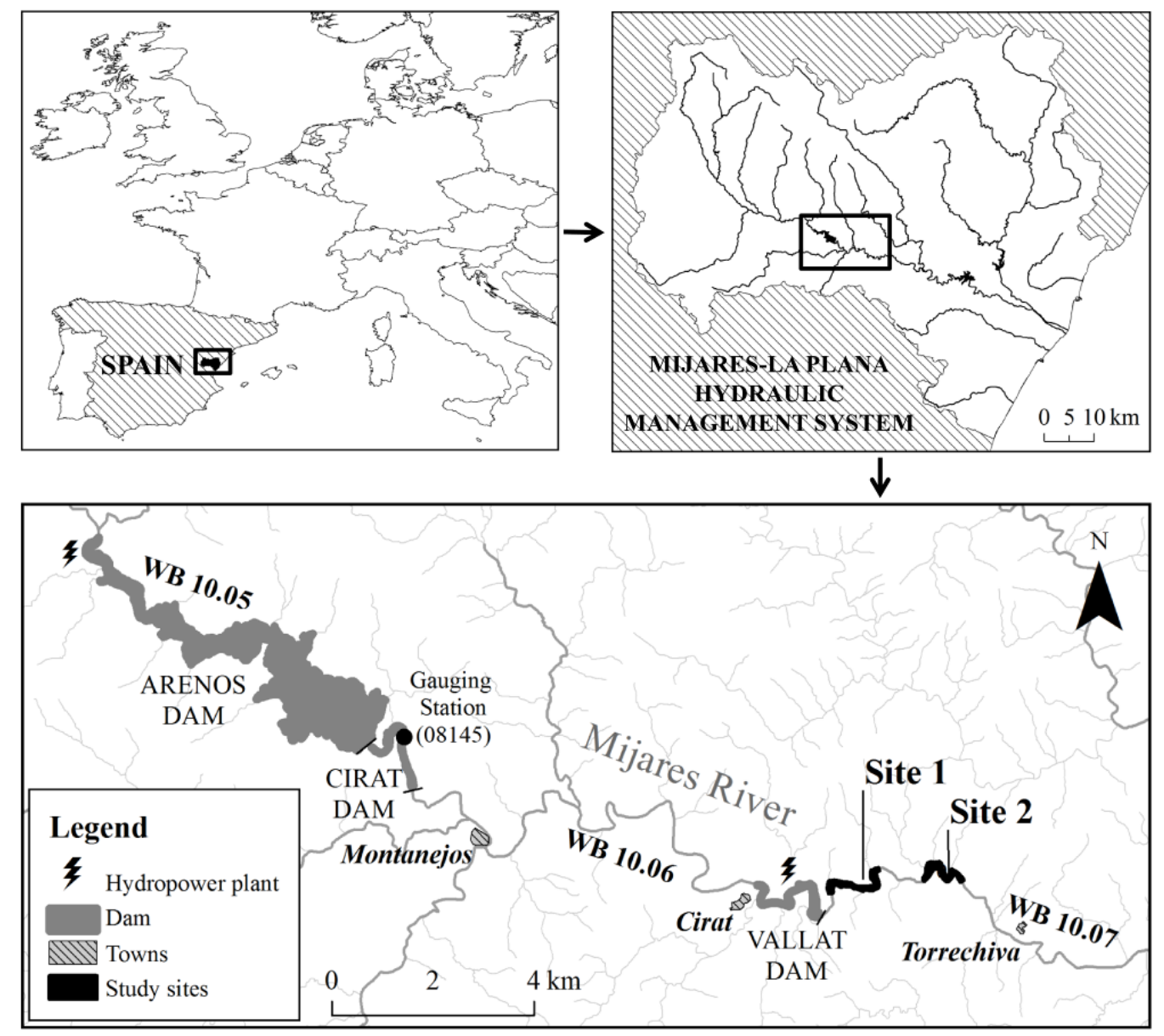

Figure 1. Location of the study sites in the Mijares River, downstream of the Arenós, Cirat and Vallat dams (built in 1979, 1962 and 1968, respectively) in the Júcar River Basin District, East Spain. Main towns of the study area and water bodies are also indicated.

Human actions have increasingly impacted the river's regime over the last 60 years as a result of changes in demographics and demands for water for hydropower, agriculture, domestic and industrial consumption. The human population in the basin increased by $73 \%$ during the $20^{\text {th }}$ century, especially from 1960 onwards, driving an increasing demand for water. However, population dynamics have been spatially highly variable. For example, the middle basin has experienced a continuous decrease in population from 1900, whereas the population in the coastal area increased by over 90\% between 1940 and 2010 (Instituto Español de 
Estadística: http://www.ine.es/). This illustrates demographic movements from rural to urban areas as well as abandonment of farm land in the upper and middle basin and remarkable agricultural intensification in the lower basin. The total irrigated area in the basin has increased by $76 \%$ since 1950 , with a particularly high expansion since 1980. Water for irrigation is abstracted directly from the river (41\%) and pumped from groundwater $(59 \%)$. The course of the river is interrupted frequently by dams and weirs associated with water abstractions, of which the Arenós dam is the largest in the Mijares basin. This impoundment provides water to two hydropower plants Cirat and Vallat (built in 1962 and 1968, respectively), which, together with five other plants along the river, provide $13 \%$ of the hydroelectric capacity in the Valencian region. As a result of these human activities, the maximum river flows in the lower basin now take place in August and September, and the aquifer has become overexploited so that the lower part of the river loses water and sea water intrusion occurs near the coast, especially in drought periods (Quereda et al., 2004). In addition, 26\% of the entire river length suffers hydromorphological impacts due to the management and presence of hydropower plants (CHJ, 2009).

This paper is concerned with the impact of the aforementioned activities on the riparian zone in the middle course of the river, which extends approximately $44 \mathrm{~km}$ downstream from the Arenós dam (Figure 1) and is upstream of the main area of population growth and intensification of agriculture. In this area, it is possible to observe changes in the structure of the riparian zone in response to increasingly severe river regulation over the $20^{\text {th }}$ century, particularly since the 1960 s, in a location where there is declining direct human pressure on the river margins. For this study to be carried out, a representative segment $4065 \mathrm{~m}$ long was selected in the middle course of the Mijares River, close enough to the main impoundments to isolate their impacts on vegetation because farther downstream, additional factors become increasingly influential (agriculture, urbanization, quarries, etc.). Three major properties of this segment are characteristic of the river's middle reaches, making the segment suitable for the purposes of the present analysis. First, the riparian habitat quality in this segment is classed as 'moderate' (Riparian Habitat Quality Index QBR; Munné et al., 2003), which is the same as $55 \%$ of the middle river course (Aguilella et al., 2005), with a limited presence of the invasive giant reed Arundo donax, which is much more abundant in wider sections downstream. Second, the vegetation composition in this segment is also similar to the rest of the middle course (Aguilella et al., 2007), consisting of the Vinco difformis-Populo albae geosigmetum, whose potential mature stage (Vinco-Populetum albae) corresponds to a forest dominated by white poplar (Populus alba) and black poplar (Populus nigra), and a willow shrub community (Coriario myrtifoliae-Salicetum angustifoliae) in the areas near the water's edge. Lastly, the sinuosity of the river segment, which is greater than 1.5, denotes a meandering pattern that is characteristic of the middle course.

Within the study segment, two alluvial reaches were selected for detailed analysis (Figure 1), where the valley bottom and its alluvial sediments were sufficiently wide for the unrestricted development of riparian vegetation. The intervening reach was omitted because it is closely confined by hillslopes, limiting the potential for riparian woodland development. These two study sites are located between 310 and $340 \mathrm{~m}$ above sea level. Table 1 summarizes their characteristics and their distance downstream from the outflows of three upstream dams (Vallat, Cirat and Arenós; Figure 1). The area studied at each site was delimited by the 500-year flood contour as computed by the Júcar River Basin Authority (CHJ, 2005) with the 1D model MIKE 11 (Danish Hydraulic Institute, 2003) with upstream and downstream ends delimited by transects perpendicular to the main flow direction. This provided an objective and consistent method for delimiting each study site, which included the entire riparian corridor. Both sites were approximately $90 \mathrm{~m}$ wide (site 1 : 60 to $120 \mathrm{~m}$; site 2: 40 to $170 \mathrm{~m}$ ). At both sites, the river bed is comprised of gravel and cobble-sized sediments, and the banks consist of sand, gravel and cobbles. Bedrock outcrops and large jagged boulders delivered from the adjacent slopes are frequent features of the river corridor and channel at both sites.

Table I. River length, catchment area, slope, sinuosity and distance along the river to upstream impoundments of the two study sites on the Mijares River, Spain.

\begin{tabular}{cccccccc}
\hline \multirow{2}{*}{ Site } & \multirow{2}{*}{ River length } & \multirow{2}{*}{ Catchment area $\left(\mathbf{k m}^{2}\right)$} & Slope (\%) & Sinuosity & \multicolumn{3}{c}{ Distance from dam(km) } \\
\cline { 6 - 8 } & & & & & Arenós & Cirat & Vallat \\
\hline 1 & 1640 & 1798 & 0.61 & 1.55 & 18.25 & 15.88 & 0.67 \\
2 & 1410 & 1805 & 0.70 & 1.86 & 20.90 & 18.53 & 3.32 \\
\hline
\end{tabular}




\section{METHODS}

\section{River flow estimation and characterization at the study sites}

There is no long-term flow record for the Mijares River close to the study sites, and so several data sources (Table 2) were combined to estimate flow records for the periods between the 1956, 1976, 1997 and 2007 aerial images that were analysed to assess land cover change (see section on Changes in Land Cover Assessed from Aerial Images). According to the period, different calculations were performed, using the sources listed in Table 2, to estimate a monthly flow record reflecting relevant available flow records and other information on the flow manipulations that were active:

- Before the 1956 image (pre-regulation), river flows were natural apart from water abstraction for irrigation. It is estimated that $50 \%$ of the water demanded by the traditionally irrigated lands is returned to the river (Paredes-Arquiola et al., 2008).

- Between the 1956 and 1976 images (pre-regulation and hydropower operation), river flows were divided into two sub-periods. For 1956-1967 (pre-regulation), although the Cirat hydropower plant started to operate in 1962, the return of the bypass is upstream of both sites, and so irrigation abstraction remained the main human manipulation of river flows. From 1968 to 1976 (hydropower operation), the Vallat dam commenced operation, with a maximum abstraction of over $12 \mathrm{~m} / \mathrm{s}$ impacting on flows at the study sites.

- Between the 1976 and 1997 images (hydropower and dam operation), it was not possible to investigate flows during the first three years (1976-1979) because the river was managed for the construction of the dam, and there are no reliable data. From 1979, the Arenós dam came into operation, having a major effect on flows at the study sites in addition to the pre-existing hydropower and irrigation activities.

- Between the 1997 and 2007 images (hydropower and dam operation), flow manipulations continued as a result of operation of the same hydropower plants that affected the river in 1997 plus irrigation abstractions.

Table II. Summary of the sources of river flow data and their attributes used to estimate a monthly flow record for the study sites (for locations of dams, water bodies and a gauging station, see Figure 1).

\begin{tabular}{|c|c|c|c|c|}
\hline Data source & Period & $\begin{array}{c}\text { Estimated } \\
\text { maximum } \\
\left(\mathrm{hm}^{3} / \text { month }\right)\end{array}$ & Time scale & Description/source \\
\hline $\begin{array}{l}\text { Reconstruction of natural } \\
\text { inflows at Arenós* }\end{array}$ & $1940-1976$ & 52.94 & Monthly & $\begin{array}{l}\text { Professor Juan Marco Segura } \\
\text { (unpublished data) }\end{array}$ \\
\hline $\begin{array}{l}\text { Simulation for water body } \\
10.05\end{array}$ & $1940-2007$ & 72.35 & Monthly & $\begin{array}{l}\text { Rainfall-runoff simulation with } \\
\text { PATRICAL model** }\end{array}$ \\
\hline $\begin{array}{l}\text { Simulation for water body } \\
10.06\end{array}$ & $1940-2007$ & 130.68 & Monthly & $\begin{array}{l}\text { Rainfall-runoff simulation with } \\
\text { PATRICAL model** }\end{array}$ \\
\hline $\begin{array}{l}\text { Arenós Gauging Station } \\
\text { (below the dam; code 08145) }\end{array}$ & $1987-2007$ & 54.74 & Daily & Júcar River Basin Authority \\
\hline Water abstraction for irrigation & $1940-2007$ & 0.23 & Monthly & $\begin{array}{l}\text { Estimation considering Water } \\
\text { Demand Units and irrigated area }\end{array}$ \\
\hline Water rights for hydropower & $1962-2007$ & 32.18 & Daily & $\begin{array}{l}\text { Water diverted into bypass } \\
\text { channel }\end{array}$ \\
\hline $\begin{array}{l}\text { Water leakage below Vallat } \\
\text { dam }\end{array}$ & $1968-2007$ & 0.27 & Daily & Filtrations of Vallat dam \\
\hline
\end{tabular}

* This location refers to the point where Arenós dam is now.

** (Pérez-Martín, 2005). 
Eleven hydrological indices, which are relevant for the river ecosystem (Olden and Poff, 2003; Mathews and Richter, 2007; Monk et al., 2007), were estimated from the flow record. The selected indices were a sub-set of those described by Belmar et al. (2011) to characterize Mediterranean rivers whilst avoiding redundancy. The selected indices describe typical or average conditions (mean annual flow - MADIS; median annual flow - Q50), variability (maximum annual discharge minus minimum annual discharge - RANGE; the coefficient of variation of mean annual flows - CVinter; the coefficient of variation of mean monthly flows CVintra), high flows (maximum annual discharge divided by Q50 - AMAX/Q50; mean of the mean maximum monthly flows for all months - MH13; coefficient of variation in mean maximum monthly flows - CVH) and low flows (minimum annual flow divided by Q50 - AMIN/Q50; mean of the mean minimum monthly flows for all months - ML13; the percentage of months when the average flow was smaller or equal to $0.1 \mathrm{~m}^{3} / \mathrm{s}-$ DL 0.1$)$. The last parameter represents the present minimum- flow conditions in the study area (approximate value of water leakage below Vallat dam).

\section{Changes in land cover assessed from aerial images}

Four sets of aerial images were identified to assess land cover at the study sites in 1956, 1976, 1997 and 2007. The 1956 and 1976 images were originally in black and white, and the 1997 and 2007 images were in colour. The July 1956 image came from the Centro Cartográfico y Fotográfico del Ejército del Aire (scale 1:10 000; pixel size $0.7 \mathrm{~m}$ ). The March 1976 image was obtained from the Confederación Hidrográfica del Júcar (scale 1:1500; pixel size 0.1 m). Images for November 1997 and August and September 2007 came from the Instituto Cartográfico Valenciano (scale 1:5000; pixel size $0.5 \mathrm{~m}$ ). River discharges at the time of these surveys were $8.1,0.1,0.09$ and $0.09 \mathrm{~m}^{3} / \mathrm{s}$, respectively.

The images were imported into ArcGISTM version 9.3 (ESRI, Redlands, CA, USA, 2009). The 1976 imagery required geo-correction, and all images were registered to European Datum 1950 and UTM-Zone 30N. To perform a comparison among images that was unbiased by differences in their colour quality and spatial resolution, we converted the 1997 and 2007 images to greyscale and re-sampled the 1976, 1997 and 2007 images to match the $0.7-\mathrm{m}$ resolution of the 1956 images.

The images were then interpreted to identify changes in land cover. The margins of each land cover patch across the entire river corridor were manually digitized, and an attribute table was created for the resulting polygons, including their code, perimeter $(\mathrm{m})$ and area $\left(\mathrm{m}^{2}\right)$. Land cover types attributed to the polygons in the most recent images were checked in the field during spring 2010 over $70 \%$ of the area of the study sites. This provided a means of verifying the attribution of land cover to the following seven classes: water (WA: open water), bare sediment (BS: cobbles, gravel and sand with vegetation cover lower than 5\%), herbs (HE: non-woody vegetation), sparse woody vegetation (SV: areas with woody herbs and small patchy shrubs and trees with a canopy cover less or equal to 40\%), dense woody vegetation (DV: areas with a dense woody canopy cover, typically higher than 60\%), cultivated (CU: farming land) and shade (SH: dark areas that could not be interpreted in the images). Because the aerial images were taken during different flow conditions, the active channel was defined as the union of water (WA) and bare sediment (BS) when the latter polygons were located immediately adjacent to the former, to permit analysis of changes in channel width and position (Takahashi and Nakamura, 2011). Pearson's chi-squared test was used to compare the resultant land cover maps, firstly comparing both sites within the same period and secondly comparing the maps for each site across periods.

The land cover information derived from the aerial images was analysed in two different ways to interpret changes in the structure and configuration of the riparian corridor. First, landscape metrics were extracted using the vector information describing land cover patch boundaries. The Patch Analyst Tool version 4 for

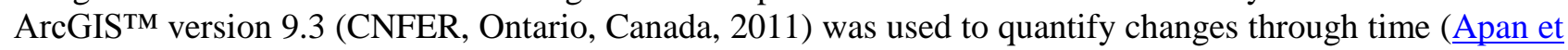
al., 2000) in a set of metrics (Table 3) that are thought to be meaningful when assessing landscape changes (Fernandes et al., 2011). Second, the vector files were converted to 5-m resolution raster layers depicting the seven land cover types. The raster maps were overlain chronologically, and a mask was employed to exclude areas affected by shade ( $\mathrm{SH})$ from the analysis. Three confusion matrices were obtained from these chronological overlays for each site, quantifying the detailed changes ('cell-by-cell comparison') between land cover types from one image to the next. The spatial distribution of agreement was summarized by the correctly classified instances (CCI), which is the total rate of pixels classified in the same category in both maps. Additionally, the Map Comparison Kit version 3.2.2 (Research Institute for Knowledge Systems, The Netherlands, 2011) was used to confirm the temporal/spatial changes detected (Visser and de Nijs, 2006). Each pair of categorical raster maps was compared chronologically for each site on the basis of fuzzy set 
theory, where both fuzziness in category definition and fuzziness in location were considered (Hagen, 2003; Hagen-Zanker et al., 2005).

Table III. Definitions of the landscape metrics extracted for land cover patches in the present study (adapted from McGarigal and Marks, 1994; McGarigal and Marks, 1995).

\begin{tabular}{|c|c|}
\hline Statistic name and abbreviation & Description \\
\hline \multicolumn{2}{|l|}{ Patch density and size metrics } \\
\hline Number of patches (NumP) & Total number of patches \\
\hline Mean Patch Size (MPS) & Average size of patches $\left(\mathrm{m}^{2}\right)$ \\
\hline Patch Size Standard Deviation (PSSD) & Standard deviation of patch areas \\
\hline Patch Size Coefficient of Variance (PSCoV) & Coefficient of variance of patches \\
\hline \multicolumn{2}{|l|}{ Edge metrics } \\
\hline Total Edge (TE) & Total perimeter of patches $(\mathrm{m})$ \\
\hline Edge Density (ED) & Amount of edge relative to the landscape area $\left(\mathrm{m} / \mathrm{m}^{2}\right)$ \\
\hline Mean Patch Edge (MPE) & Average amount of edge per patch \\
\hline \multicolumn{2}{|l|}{ Shape metrics } \\
\hline Mean Shape Index (MSI) & $\begin{array}{l}\text { Shape complexity. Equals one when all patches are circular and it } \\
\text { increases with the patch shape irregularity }\end{array}$ \\
\hline Mean Perimeter Area Ratio (MPAR) & $\begin{array}{l}\text { Shape complexity. Sum of the perimeter/area ratio for all patches } \\
\text { divided by number of patches }\end{array}$ \\
\hline Mean Patch Fractal Dimension (MPFD) & $\begin{array}{l}\text { Shape complexity. Approaches one for shapes with simple } \\
\text { perimeters and two when shapes are more complex }\end{array}$ \\
\hline \multicolumn{2}{|l|}{ Diversity metrics } \\
\hline Shannon's Diversity Index (SDI) & $\begin{array}{l}\text { Relative measure of patch diversity. Equals zero when there is only } \\
\text { one patch in the landscape and increases as the number of patch } \\
\text { types and/or proportional distribution of patch types increases }\end{array}$ \\
\hline Shannon's Evenness Index (SEI) & $\begin{array}{l}\text { Measure of distribution of area among patch types. Equals zero } \\
\text { when there is no diversity (i.e. a single patch type) and one when the } \\
\text { distribution of patch types becomes perfectly even }\end{array}$ \\
\hline
\end{tabular}

The fuzziness of categories was implemented by assigning to each cell a membership vector instead of a single category. Each element in the vector declares, with a value between 0 (crisply distinct) and 1 (completely identical), the degree of membership for one category (Hagen, 2002; Hagen, 2003; van Vliet et al., 2010). All this information is gathered in the category similarity matrix, where similarity between categories decreases when distance from the diagonal increases. Only similarities between the types BS, HE, SV and DV were considered (according to the definitions stated earlier). The consistency of the resultant matrix was tested using the analytic hierarchy process developed by Saaty (1980). The fuzziness of location considers that the fuzzy representation of a cell depends on the cell itself and, to a lesser extent, on the cells within a certain distance in its neighbourhood (Hagen, 2003). The extent to which the neighbouring cells influence the fuzzy calculation is represented by a distance decay function. In this study, a linear decay (cone shape, defined by slope $=0.5$ ) and a radius of neighbourhood of two cells (equivalent to a $10-\mathrm{m}$ radius) were considered as appropriate. 
Two global similarity indices were used to assess the similarity between the maps of fuzzy membership vectors: average similarity and fuzzy kappa. The average similarity is the fuzzy equivalent of the CCI (also known as 'fraction correct' or 'observed percentage of agreement'). The fuzzy kappa statistic is similar to the traditional Cohen's kappa (1960), i.e. the percentage of agreement between two maps is corrected for the fraction of agreement statistically expected if all cells were randomly relocated in both maps. Briefly, it corrects the percentage of agreement for the expected percentage of agreement based upon the histograms of the two maps.

\section{Changes in land cover assessed from field survey}

A detailed vegetation survey was conducted within a part of site 2 in 2007 . The survey was conducted along transects across the riparian corridor perpendicular to the main flow direction and including the river channel (Garófano-Gómez et al., 2008). All individual riparian woody plants were surveyed within each transect. The outer limits of the vertical projection of each plant or tree canopy on each transect were recorded using a total station and Global Positioning System. The canopy height and stem diameter at $50 \mathrm{~cm}$ above ground for shrub species and at $130 \mathrm{~cm}$ for tree species were recorded for every woody plant.

Core samples were obtained from the target riparian woody species across the study area and surroundings, but always within the middle course of the river, using pruning shears for small individuals and a Pressler drill for the large ones. These core samples were dried and sanded to increase the visibility of the annual growth rings, which were counted to estimate the age and to develop age-diameter relationships for each species. The target woody species and the number of core samples were as follows: rosemary willow (Salix eleagnos Scop.; $\mathrm{N}=26$ ), large grey willow (Salix atrocinerea Brot.; $\mathrm{N}=13$ ), tamarisk (Tamarix spp.; $\mathrm{N}=9$ ), black poplar ( $P$. nigra $\mathrm{L}$.; $\mathrm{N}=27$ ), oleander (Nerium oleander $\mathrm{L} . ; \mathrm{N}=24$ ) and redoul (Coriaria myrtifolia $\mathrm{L}$.; $\mathrm{N}=11$ ). The age-diameter relationships were used to estimate the age of all surveyed plants and thus the period (image) when they were established. The locations of the surveyed plants were overlain on the aerial images to identify the land cover type within which they germinated and established.

\section{RESULTS}

\section{Changes in river flow regime}

Figure 2 summarizes trends in monthly flows within the four periods between the dates of the analysed images, indicating trends within sub-periods where there is a significant change in flow regulation activities. The pre-regulation periods (1940-1956 and 1957-1967) show an essentially natural flow regime (apart from water abstraction for irrigation that affects the entire 1940-2007 period), characterized by relatively high average flows that vary widely between and within months. Following the development of the Cirat dam from 1962, peak flows were impacted but not the largest ones. Two large floods also occurred during this pre-regulation period (14 October 1957 and 24 October 1967). The magnitude of these two extraordinary events was not measured, but local newspapers (e.g. the ABC newspaper, http://hemeroteca.abc.es) reported that they destroyed several gauging stations and bridges, and so they probably caused severe disturbance to the riparian zone. Following the closure of the Vallat dam in 1968, the flow regime was transformed (Figure 2), with almost all the flow diverted for hydropower production. From 1968, the riverbed was virtually dry for the majority of the time (Prof. J. Marco Segura, personal communication), with occasional higher flows occurring during exceptional storms or when the dam gates were opened to manipulate reservoir levels. As a result, since 1968, the median monthly flow and flow variability (indicated by the $10^{\text {th }}$ and $90^{\text {th }}$ percentiles) have been drastically reduced (Figure 2).

These changes in flow are reflected in the values of the hydrological indices representing average-flow, highflow and low-flow conditions during the four periods (Table 4). The mean annual flow (MADIS) shows a dramatic decrease, from around $6 \mathrm{~m}^{3} / \mathrm{s}$ prior to 1968 to less than $0.5 \mathrm{~m}^{3} / \mathrm{s}$ post-regulation, and the median (Q50) is even more severely affected, with a reduction of approximately $98 \%$. Flow variability is also greatly modified with a major reduction in the range (maximum minus minimum) of mean annual flows following dam closure (RANGE) apart from those in 1979-1997, during which large rain storms occurred in 19891990. There is also up to a tenfold increase in the coefficient of variation of flows between months (CVintra) and years (CVinter), reflecting the fact that the early years with a natural flow regime had a higher mean flow when compared with their (also higher) standard deviation. 

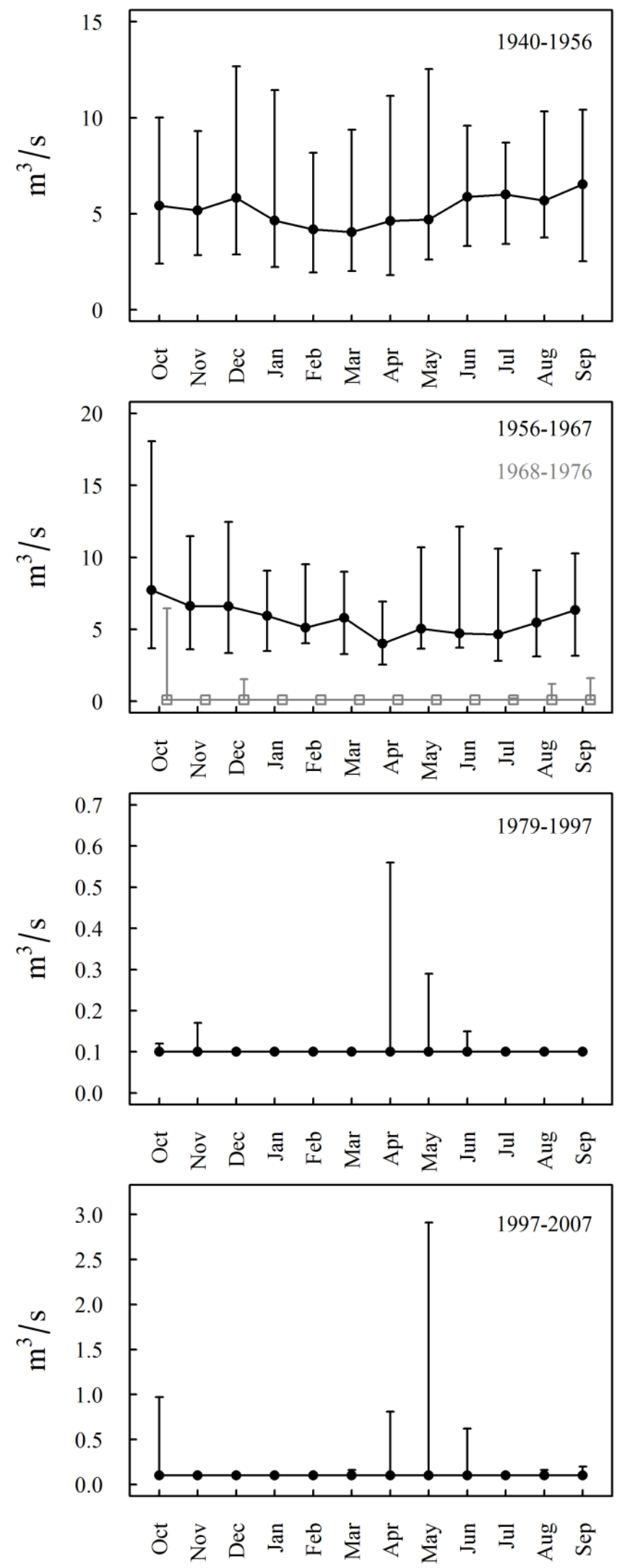

Figure 2. The $90^{\text {th }}$ and $10^{\text {th }}$ percentiles (bars) and median of monthly flows within the designated months and periods. Note that the scale of the vertical axes varies between graphs to improve visualization and that different line colours (black, grey) and symbols (dots, squares) are used to depict data when the flow time series between images has been split into sub-periods. 
Table IV. Hydrological indices for the analysed flow periods.

\begin{tabular}{lccccc}
\hline & $\mathbf{1 9 4 0 - 1 9 5 6}$ & $\mathbf{1 9 5 6 - 1 9 6 7}$ & $\mathbf{1 9 6 8 - 1 9 7 6}$ & $\mathbf{1 9 7 9 - 1 9 9 7}$ & $\mathbf{1 9 9 7 - 2 0 0 7}$ \\
\hline Average flow conditions & & & & & \\
$\quad$ MADIS & 5.991 & 6.430 & 0.385 & 0.411 & 0.304 \\
$\quad$ Q50 & 5.568 & 6.680 & 0.195 & 0.100 & 0.099 \\
$\quad$ RANGE & 8.901 & 6.762 & 0.882 & 4.075 & 0.736 \\
$\quad$ CVintra & 0.115 & 0.159 & 1.395 & 1.098 & 1.014 \\
$\quad$ CVinter & 0.414 & 0.322 & 0.957 & 2.359 & 0.996 \\
High flow conditions & & & & & \\
$\quad$ AMAX/Q50 & 2.115 & 1.537 & 5.028 & 41.741 & 8.436 \\
$\quad$ MH13 & 13.378 & 13.422 & 1.894 & 5.530 & 1.867 \\
$\quad$ CVH & 0.142 & 0.224 & 1.610 & 1.475 & 1.443 \\
Low flow conditions & & & & & \\
$\quad$ AMIN/Q50 & 0.516 & 0.524 & 0.512 & 0.987 & 0.997 \\
$\quad$ ML13 & 1.341 & 2.733 & 0.100 & 0.095 & 0.099 \\
Duration of low flow conditions & & & & & \\
$\quad$ DL0.1 (\%) & 0 & 0 & 93 & 91 & 92 \\
\hline
\end{tabular}

With respect to high flows, the average of maximum monthly flows (MH13) is approximately $13 \mathrm{~m}^{3} / \mathrm{s}$ before 1968 and lower than $2 \mathrm{~m}^{3} / \mathrm{s}$ post-regulation, with the exception once again of those in 1979-1997. The variability across maximum monthly flows $(\mathrm{CVH})$ has increased post-regulation because flows of an intermediate magnitude are very rare, and AMAX/Q50 shows a similar change due to the low postregulation frequency of floods and the low values of the median annual flows. In relation to low-flow conditions are the following: (i) average minimum monthly flows have decreased dramatically, with ML13 not exceeding $0.1 \mathrm{~m}^{3} / \mathrm{s}$; (ii) the percentage of months with flow equal to or lower than $0.1 \mathrm{~m}^{3} / \mathrm{s}$ (DL0.1) has exceeded 90\% since 1968; and (iii) AMIN/Q50 has remained approximately equal to 1 from 1979 (after the Arenós dam was built), indicating minimal differences between the minimum and median flows.

\section{Changes in the areal extent and distribution of riparian land cover types}

The areal extent and distribution of land cover types within the river corridor has changed dramatically during the last six decades (Figures 3 and 4). Before regulation (1956), the land cover types were present in similar proportions (Figure 4), the channel (water and bare sediment) was relatively wide and the most developed cover type (dense woody vegetation, DV) was often found set back from the margins of the active channel (Figure 3). Following regulation, there was an initial increase in bare sediment cover as the water area decreased (1976; Figure 3), and then vegetation started to colonize, with herbs (HE), followed by sparse shrubby vegetation (SV) and then by dense and more mature tree cover (DV), in turn encroaching across the river corridor (1976, 1997 and 2007; Figure 3) and leading to the virtual disappearance of bare sediment (BS) and early vegetation stages in 2007. The largest area of water (WA) is observed in the 1956 image with a dramatic decrease at both sites at all later dates (Figure 4). The highest percentage of bare sediment (BS) was found at both sites in 1976. Herbaceous cover (HE) is always more abundant at site 1 and, like BS, reached maximum cover in 1976. In contrast, dense vegetation (DV) achieved minimum cover in 1976, increasing greatly in cover in 1997 and 2007 and always showing a higher cover at site 1. Cultivated land (CU) extends across a sizeable area in 1956 but then reduces to $8 \%$ or less in all subsequent images.

Figure 5 illustrates the relative change in active channel area (WA plus adjacent BS) since 1956. There is a similar trend of reduction in channel area at both study sites to 1976, although the reduction at site 2 is smaller (93\%) than that at site $1(73 \%)$, with a larger reduction at both sites between 1976 and 1997 than between 1956 and 1976. Since 1997, there has been a small increase in active channel area at the two sites. 

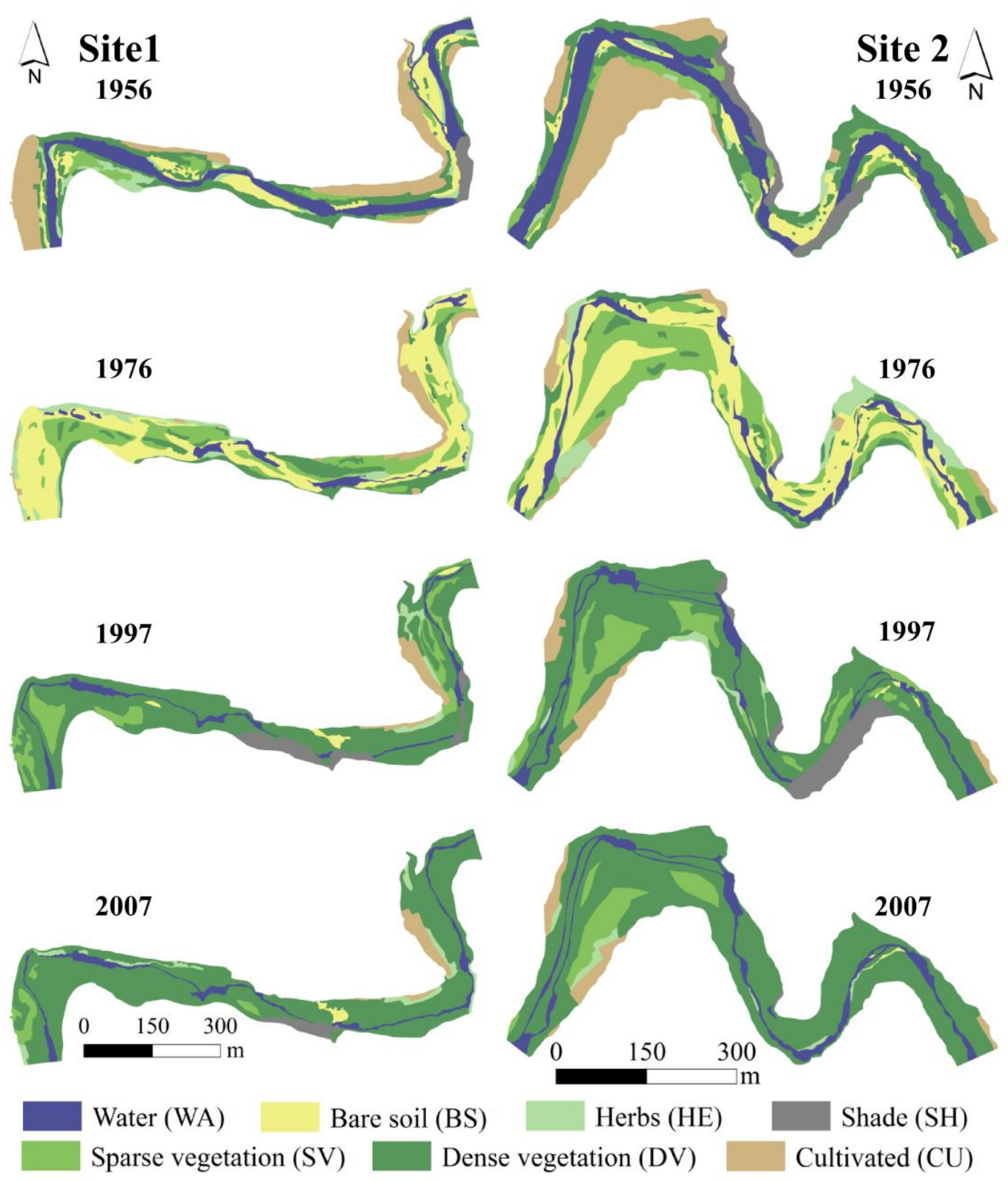

Figure 3. Land cover maps for the pre-regulation (1956) and post-regulation periods (1976, 1997 and 2007) at both study sites.

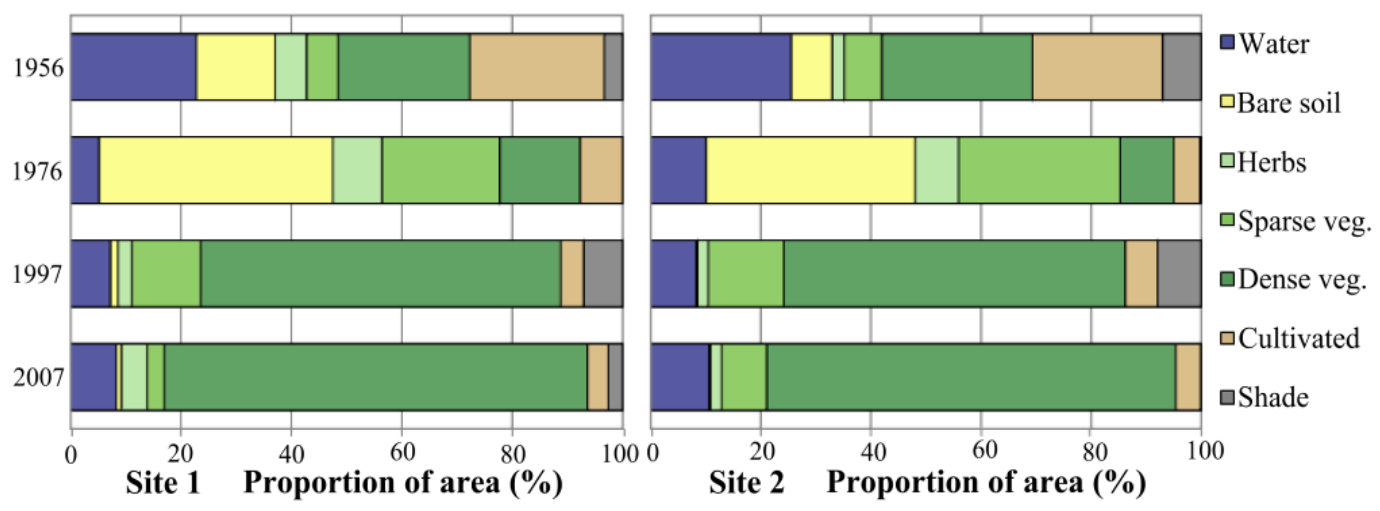

Figure 4. Proportion of area cover by each land cover type in both study sites. 


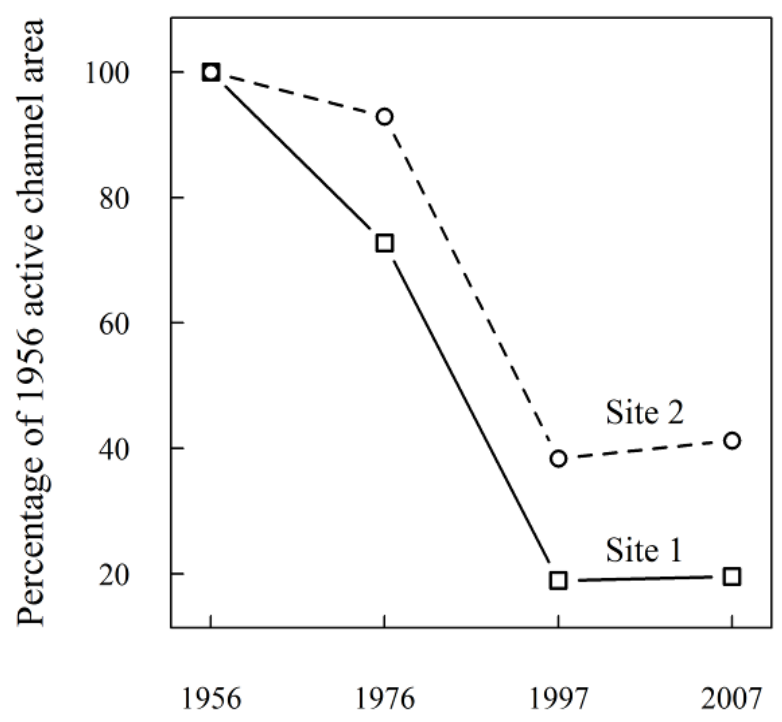

Figure 5. Active channel area in 1956, 1976, 1997 and 2007, expressed as a percentage of that observed at both study sites in 1956.

\section{Riparian landscape structure}

The riparian landscape structure, in terms of the number (Table 5) and size and shape (Table 6) of land cover patches, has changed greatly over the study period. The number of land cover patches has decreased by over 50\% between 1956 and 2007, with a particularly steep decrease between 1976 and 1997 (Table 5). In relation to the particular land cover types, WA showed the largest number of patches in 1976, along with SV, DV and CU, whereas BS and HE patches were most numerous in 1956 across the two study sites. The two sites show remarkably similar patch numbers in each of the four images. Pearson's chi-squared test performed with the number of patches by cover type as well as with their proportions (Table 5) indicated no significant differences between sites within each period, confirming their similar morphology and vegetation dynamics and likely representativeness of the middle course of the river. However, differences across periods for both sites were significant in all cases.

The calculated landscape metrics (Table 6) allow the complexity of land cover to be further explored between sites and periods. The metrics are remarkably similar at the two study sites at each date, although some small differences can be identified. However, there are notable changes in each metric between dates. Site 2 shows patches with a more complex shape than those in site 1, and patches before 1976 had higher shape complexity than those in 1997-2007 (mean perimeter area ratio, Table 6). In general, mean patch size (Table 6) was larger at site 1 than at site 2, decreased across both sites by 13\% from 1956 to 1976 and then increased by $103 \%$ from 1976 to 1997 and by 53\% from 1997 to 2007. The standard deviation of patch size (Table 6) increased from 1956 to 2007 at both sites, but there was no consistent trend in patch size coefficient of variance (Table 6).

Table V. Number of patches by land cover type for the aerial images at both study sites (site 1, upstream; site 2, downstream).

\section{Cover Type}

\begin{tabular}{ccccccccccccccc} 
& \multicolumn{3}{c}{ WA } & \multicolumn{1}{c}{ BS } & \multicolumn{2}{c}{ HE } & \multicolumn{2}{c}{ SV } & \multicolumn{2}{c}{ DV } & \multicolumn{3}{c}{ CU } \\
\cline { 2 - 12 } Date/Site & Site 1 & Site 2 & Site 1 & Site 2 & Site 1 & Site 2 & Site 1 & Site 2 & Site 1 & Site 2 Site 1 Site 2 \\
\hline 1956 & 2 & 2 & 15 & 14 & 16 & 12 & 8 & 11 & 25 & 27 & 5 & 6 \\
1976 & 14 & 9 & 5 & 12 & 11 & 7 & 18 & 26 & 21 & 35 & 10 & 6 \\
1997 & 4 & 3 & 3 & 3 & 3 & 6 & 7 & 12 & 14 & 11 & 2 & 3 \\
2007 & 2 & 2 & 1 & 2 & 8 & 5 & 4 & 4 & 7 & 7 & 3 & 4 \\
\hline
\end{tabular}


In relation to the edge metrics, there was a reduction in total edge length (Table 6) from 1956 to 2007 with a slight increase in 1976, whereas mean patch edge length (Table 6) showed an opposite tendency, with higher values in 2007 than in 1956. Overall, the most recent images show larger (area and perimeter), less abundant and less complex patches, whereas the oldest images show smaller, more numerous and more complex patches.

In relation to patch shape, the mean shape index (Table 6) indicates circular polygons as its value approaches 1 and more complex, irregular polygons as its value increases. Mean shape index values are consistently higher for site 1 and are lowest for the 1956 and 1976 images. The mean patch fractal dimension (Table 6) achieved values in the range of 1-2 (the closer the value to 2 , the more complex is the perimeter), with site 2 always showing higher values than site 1 and the 1956 and 1976 images showing higher values than the 1997 and 2007 images. Both patch diversity indices (Table 6) showed a similar decreasing trend through the study period. Although all the land cover types were present at all four dates (i.e. the same patch richness), the number of patches of all the types varied greatly between periods (Table 5), with more patches and also more similarly sized patches in the early images and with fewer patches dominated by a single cover type in later images (Figure 3, Table 6).

Table VI. Landscape metrics for study sites 1 and 2 for the images from 1956, 1976, 1997 and 2007 (the metrics codes are explained in Table 3).

\begin{tabular}{|c|c|c|c|c|c|c|c|c|}
\hline & \multicolumn{8}{|c|}{ Date (Site) } \\
\hline & 1956(1) & $1956(2)$ & 1976(1) & 1976(2) & 1997(1) & 1997(2) & 2007(1) & $2007(2)$ \\
\hline \multicolumn{9}{|c|}{ Patch density and size metrics } \\
\hline NumP & 74 & 74 & 79 & 96 & 37 & 42 & 26 & 25 \\
\hline MPS & 1830 & 1520 & 1710 & 1170 & 3660 & 2670 & 5210 & 4490 \\
\hline PSSD & 3680 & 3590 & 4170 & 2680 & 7140 & 4520 & 8520 & 8910 \\
\hline PSCoV & 201 & 237 & 243 & 230 & 195 & 169 & 164 & 199 \\
\hline \multicolumn{9}{|c|}{ Edge metrics } \\
\hline TE & 23000 & 17500 & 23600 & 22000 & 19000 & 17000 & 15800 & 14900 \\
\hline $\mathrm{ED}$ & 0.170 & 0.156 & 0.174 & 0.196 & 0.140 & 0.156 & 0.117 & 0.133 \\
\hline MPE & 310 & 237 & 298 & 229 & 513 & 415 & 609 & 595 \\
\hline \multicolumn{9}{|c|}{ Shape metrics } \\
\hline MSI & 2.197 & 1.986 & 2.135 & 1.997 & 2.506 & 2.337 & 2.677 & 2.583 \\
\hline MPAR & 0.377 & 0.436 & 0.428 & 0.455 & 0.248 & 0.317 & 0.240 & 0.360 \\
\hline MPFD & 1.650 & 1.676 & 1.653 & 1.684 & 1.583 & 1.614 & 1.581 & 1.648 \\
\hline \multicolumn{9}{|c|}{ Diversity metrics } \\
\hline SDI & 1.741 & 1.690 & 1.540 & 1.545 & 1.199 & 1.233 & 0.922 & 0.905 \\
\hline SEI & 0.894 & 0.869 & 0.859 & 0.794 & 0.616 & 0.634 & 0.474 & 0.465 \\
\hline
\end{tabular}

\section{Land cover transitions}

The confusion matrices (Table 7) show percentage transitions of pixels classified under each land cover between consecutive survey dates. The total percentages of pixels that remained under the same land cover (CCI index; in cell-by-cell comparisons) between 1956 and 1976, 1976 and 1997, and 1997 and 2007 were $29 \%, 22 \%$ and $76 \%$, respectively, at site 1 and $22 \%, 21 \%$ and $79 \%$, respectively, at site 2 . The fuzzy comparisons indicated through the average similarity showed larger percentages of agreement between the maps: $47 \%, 51 \%$ and $86 \%$ at site 1 and $38 \%, 51 \%$ and $87 \%$ at site 2 . Fuzzy kappa yielded values of 0.122 , 0.146 and 0.548 for the chronological map comparisons at site 1 and $0.063,0.160$ and 0.615 at site 2; these results confirm that the more dramatic changes occurred in the first two transitions (1956-1976 and 19761997), and the largest overall similarity was obtained between the last two maps (1997 and 2007).

Notably stable land cover classes were BS and SV between 1956 and 1976 (during which around 50\% of pixels remained in these categories); DV, WA and CU between 1976 and 1997 (with around 90\% of pixels under DV, over 50\% under CU and around 50\% under WA remaining unchanged); and DV, WA and CU 
once more between 1997 and 2007 (with over 90\% under DV, over 60\% under WA and around 70-80\% under CU remaining unchanged). The most notable changes in land cover were from WA, HE and CU to BS between 1956 and 1976; from WA, BS, HE and SV to DV between 1976 and 1997; and from BS, HE and SV to DV between 1997 and 2007. Hence, DV (areas with a dense woody canopy cover) became an absorbing state at the scale of the river corridor following hydrological regulation (Table 7).

Table VII. Confusion matrices of the raster maps for both study sites.

\begin{tabular}{|c|c|c|c|c|c|c|c|c|c|c|c|c|c|}
\hline & \multicolumn{7}{|c|}{ Site 1} & \multicolumn{6}{|c|}{ Site 2} \\
\hline & & \multicolumn{6}{|c|}{1976 Image } & \multicolumn{6}{|c|}{1976 Image } \\
\hline & & WA & BS & HE & SV & DV & $\mathrm{CU}$ & WA & BS & HE & SV & DV & $\mathrm{CU}$ \\
\hline \multirow{6}{*}{ 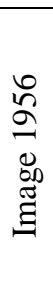 } & WA & 16 & 55 & 4 & 14 & 10 & 0 & 17 & 52 & 1 & 23 & 7 & 0 \\
\hline & BS & 3 & 52 & 1 & 36 & 7 & 2 & 10 & 52 & 3 & 24 & 12 & 0 \\
\hline & $\mathrm{HE}$ & 6 & 58 & 3 & 21 & 11 & 0 & 2 & 45 & 13 & 30 & 11 & 0 \\
\hline & SV & 0 & 15 & 7 & 49 & 28 & 0 & 10 & 31 & 3 & 51 & 5 & 0 \\
\hline & DV & 2 & 28 & 16 & 21 & 30 & 2 & 8 & 31 & 17 & 27 & 17 & 1 \\
\hline & $\mathrm{CU}$ & 0 & 40 & 10 & 17 & 5 & 28 & 0 & 31 & 8 & 36 & 7 & 18 \\
\hline & & \multicolumn{6}{|c|}{1997 Image } & \multicolumn{6}{|c|}{1997 Image } \\
\hline & & WA & BS & $\mathrm{HE}$ & SV & DV & $\mathrm{CU}$ & WA & BS & $\mathrm{HE}$ & SV & DV & $\mathrm{CU}$ \\
\hline \multirow{8}{*}{ 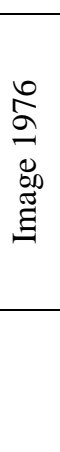 } & WA & 50 & 5 & 0 & 0 & 45 & 0 & 46 & 1 & 1 & 3 & 49 & 0 \\
\hline & BS & 12 & $\mathbf{0}$ & 3 & 22 & 63 & 0 & 12 & $\mathbf{0}$ & 2 & 22 & 63 & 1 \\
\hline & $\mathrm{HE}$ & 1 & 0 & O & 9 & 90 & 0 & 1 & 0 & 1 & 8 & 76 & 15 \\
\hline & SV & 2 & 2 & 2 & 14 & 81 & 1 & 2 & 0 & 4 & 16 & 75 & 4 \\
\hline & DV & 1 & 5 & 0 & 1 & 93 & 0 & 1 & 0 & 0 & 7 & 90 & 1 \\
\hline & $\mathrm{CU}$ & 0 & 1 & 12 & 6 & 30 & 51 & 0 & 0 & 0 & 1 & 29 & 70 \\
\hline & & \multicolumn{6}{|c|}{2007 Image } & \multicolumn{6}{|c|}{2007 Image } \\
\hline & & WA & BS & $\mathrm{HE}$ & SV & DV & $\mathrm{CU}$ & WA & BS & $\mathrm{HE}$ & SV & DV & $\mathrm{CU}$ \\
\hline \multirow{6}{*}{ 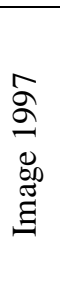 } & WA & 66 & 0 & 1 & 0 & 33 & 0 & 65 & 0 & 1 & 0 & 34 & 0 \\
\hline & BS & 1 & 43 & 0 & 0 & 56 & 0 & 9 & 36 & 0 & 0 & 55 & 0 \\
\hline & $\mathrm{HE}$ & 0 & 0 & 49 & 0 & 45 & 7 & 8 & 0 & $\mathbf{0}$ & 8 & 84 & 0 \\
\hline & SV & 0 & 0 & 5 & 12 & 84 & 0 & 3 & 0 & 1 & 47 & 50 & 0 \\
\hline & DV & 4 & 0 & 4 & 2 & 90 & 0 & 4 & 0 & 1 & 2 & 91 & 1 \\
\hline & $\mathrm{CU}$ & 0 & 0 & 10 & 0 & 6 & 84 & 0 & 0 & 12 & 0 & 20 & 68 \\
\hline
\end{tabular}

For each comparison, data for the oldest map are presented in rows and the most recent in columns. For each pair of dates, the percentage of pixels that changed from one cover type (specified in rows) to another (specified in columns) is noted. The numbers in the diagonal (in bold) represent the percentage of pixels that remained unchanged for both dates.

\section{Contemporary data (transects)}

When cross profiles of individual transects surveyed in 2007 are compared with the spatial distribution of the land cover classes along the same transects identified on the four aerial images for 1956, 1976, 1997 and 2007 (e.g. Figure 6), the accuracy of the image interpretation is confirmed, and the changes in land cover are clearly apparent. Lateral migration and narrowing of the active channel can be interpreted from these data, with implications for the space available for vegetation colonization. Evidence from the cross profiles confirm that lateral channel movements and narrowing mainly occurred between 1956 and 1976, since the channel position and width has stabilized. This stabilization has allowed the riparian corridor to be progressively colonized by vegetation, with dense woody vegetation dominating most of the riparian corridor by 2007. 

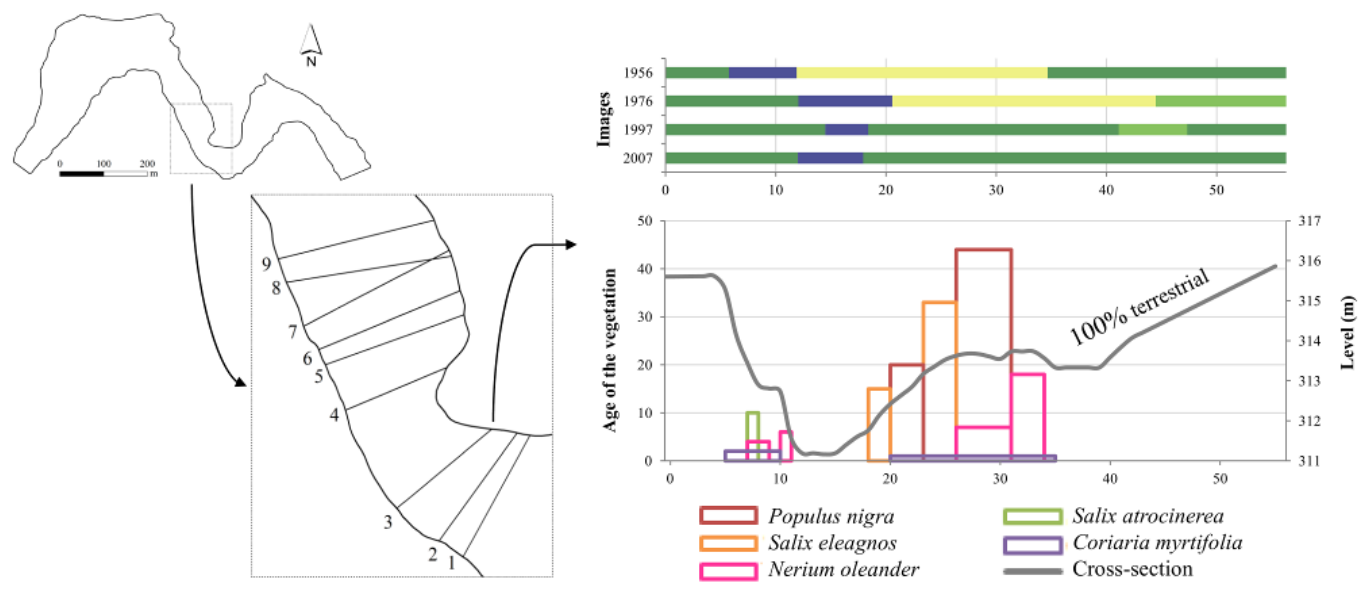

Figure 6. The cross profile and plant species-age distribution recorded for transect 3 , site 2 in 2007, in comparison with the distribution of land cover types estimated for the same cross section from the 1956, 1976, 1997 and 2007 images (cover classes presented in the same colours as in Figures 3 and 4).

Salix eleagnos $(\mathrm{N}=19)$

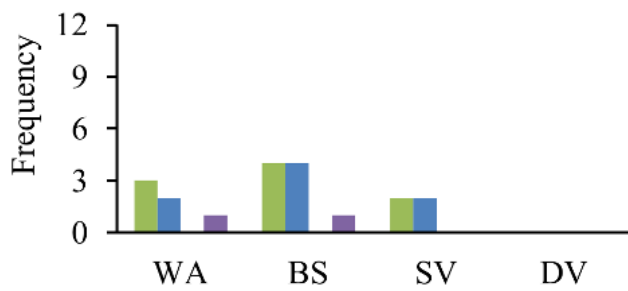

Tamarix spp. $(\mathrm{N}=17)$

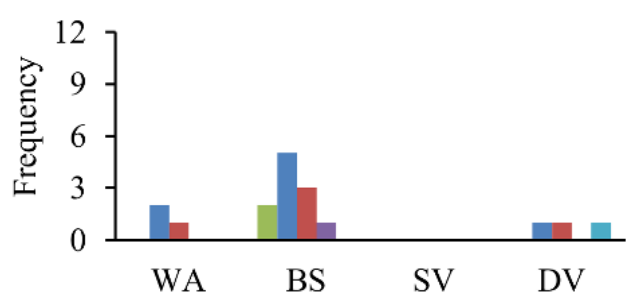

Populus nigra $(\mathrm{N}=18)$

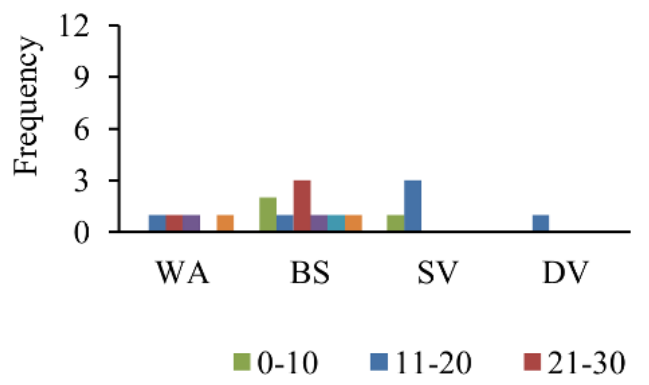

Salix atrocinerea $(\mathrm{N}=3)$

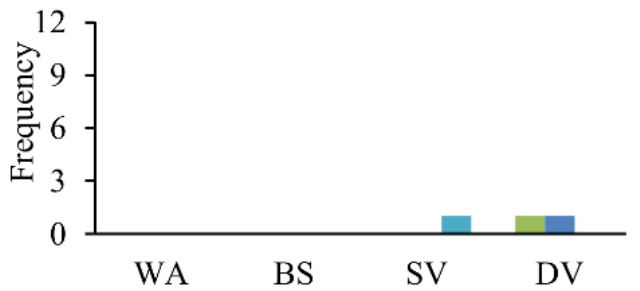

Nerium oleander $(\mathrm{N}=36)$

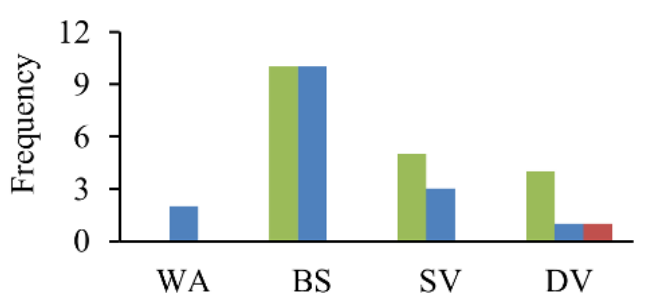

Coriaria myrtifolia $(\mathrm{N}=21)$

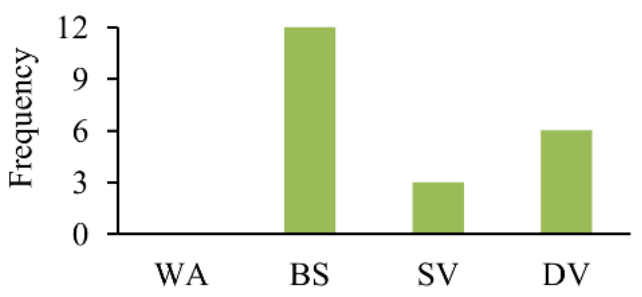

$\square 31-40 \quad \square 1-50 \quad \square>50$

Figure 7. Number of plants (frequency) of the different riparian woody species recorded in the field survey conducted in 2007 and overlaid upon the land cover types map from 1976. Each plant was assigned to an age interval of 10 years according to their age (i.e. a plant in the age interval 0-10 means that the plant was established in the period 1997-2007). Codes of land cover types refer to water (WA), bare soil (BS), sparse vegetation (SV) and dense vegetation (DV).

The field surveys by transects illustrate that a variety of riparian woody species were concentrated along the margins of the river channel in 2007, including S. eleagnos (SE), S. atrocinerea (SA), Tamarix spp. (TA), $N$. oleander (NO), P. nigra (PN) and C. myrtifolia (CM). Linear age-diameter relationships with mainly high 
coefficients of determination $\left(\mathrm{R}^{2}\right)$ were obtained for the main species as follows: ageSE $=3.4599 * \mathrm{dSE}+$ $0.5881\left(\mathrm{R}^{2}=0.6196\right)$; ageSA $=1.8604 * \mathrm{dSA}+1.8145\left(\mathrm{R}^{2}=0.8495\right)$; ageTA $=3.2664 * \mathrm{dTA}+0.281\left(\mathrm{R}^{2}=\right.$ $0.8193)$; ageNO $=3.0878 * \mathrm{dNO}+0.0258\left(\mathrm{R}^{2}=0.9199\right) ;$ agePN $=2.0849 * \mathrm{dPN}+1.832\left(\mathrm{R}^{2}=0.9812\right)$; $\operatorname{ageCM}=1.2104 * \mathrm{dCM}+0.5613\left(\mathrm{R}^{2}=0.868\right)$.

Figure 7 shows the sample size of these six species along the 2007 transects in relation to their age and the land cover type present in 1976 at the site where they were growing. From Figure 7, it is noticeable that most of the plants were less than 20 years old, with a few in the 20-30-year range and very few older than that. Indeed, $91 \%$ of the plants recorded in the 2007 survey post-date the 1976 image. Only ten of the individuals surveyed exceeded 30 years of age and were of only four species: S. eleagnos (located in WA and BS in 1976), Tamarix spp. (located in BS and DV in 1976), P. nigra (located in WA and BS in 1976) and $S$. atrocinerea (located in SV in 1976). Since 1976, the riparian corridor has been heavily colonized, with 54\% of plants colonizing areas identified as BS in 1976. The species of the younger individuals inventoried (i.e. those in the age range of 0-10 years) are largely N. oleander, S. eleagnos and C. myrtifolia, and these plants represented $43 \%$ of all of the surveyed plants, possibly indicating a shift in the species composition to species with higher tolerance to water stress.

\section{DISCUSSION}

\section{Use of historical information sources}

In a retrospective study of this type, analysis has to be based on the historical sources that are available. This is a common situation in both river research and river management contexts, and so it is important for researchers to continue to explore both the potential and the limitations of different sources in relation to river research and management applications.

In the present study, we combined historical river flow data from a gauging site, modelled river flow estimates and information on different river flow manipulation activities. This constrained our reconstructed time series to a monthly resolution. This rather coarse temporal resolution is not ideal when investigating impacts on riparian systems because riparian vegetation is highly dependent on and responsive to shorter events, particularly droughts (Mahoney and Rood, 1998; González et al., 2012) and floods (Blondel and Aronson, 1999; Naiman et al., 2008), which often form crucial elements in the definition of environmental flow regimes for riparian conservation (Rood et al., 2003; Paredes-Arquiola et al., 2011). However, only monthly data are available for many rivers and regions (Richter et al., 2012), and in the present case, this was the highest resolution to which we felt able to construct an internally consistent flow series. This resulted from a number of factors but particularly the temporal resolution and uncertainty in the quality of historical gauged records used in flow reconstructions, which are derived from stations that no longer exist and variation in the quality/uncertainty between gauged sites that remain in operation.

Another constraint on our analysis was the resolution of the images that were used to explore land cover change. Early aerial images are usually monochrome, and their spatial resolution is usually rather coarse. Just as we felt it necessary to degrade the temporal resolution of the time series to a level whereby we were confident of an internally consistent data quality, we also degraded the imagery to that of the earliest, lowestresolution images to ensure that any analytical results were not differentially affected by image resolution. This degradation also meant that it was essential for the images to be manually interpreted and digitized because their quality was insufficient for an automated procedure to generate useful outputs. Human interpretation is inevitably subjective, but to maintain consistency of interpretation, all images were interpreted and digitized by the same operator. Image degradation may also have introduced some errors in linking the land cover recorded from the field-surveyed transects to that on the images, although given the resolution of the degraded images $(0.7 \mathrm{~m})$, it is unlikely that any serious errors in our analysis can be attributed to this factor.

In the present study, combining different types of data has proven useful for reconstructing riparian changes. This type of integrated approach has been adopted in other studies using a wide variety of historical data sources. For example, at a local scale, within-patch forest metrics such as shifts in species composition, size class distribution, stem density (Shafroth et al., 2002), canopy dieback and stem mortality (González et al., 2010) can provide valuable information about vegetation response (at species level) to changing hydrologic conditions. At a landscape scale, information from herbariums (Crawford and Hoagland, 2009), archives, historical maps and land surveys (Johnson, 1994; Kondolf and Larson, 1995; Merritt and Cooper, 2000) can 
all contribute to reconstructions. Furthermore, there have been important advances in modelling that can aid reconstruction of the historical composition and development of riverine habitats under different pressures (Benjankar et al., 2011; Hohensinner et al., 2011; Benjankar et al., 2012; Egger et al., 2012).

\section{Temporal and spatial changes: the utility of indices and metrics}

Numerous indices have been proposed for summarizing ecologically relevant properties of the river flow regime (e.g. Olden and Poff, 2003; Mathews and Richter, 2007; Monk et al., 2007; Belmar et al., 2011), and we evaluated 11 of these during our study (Table 4). Although our estimates of many of these indices were probably adversely affected by the low (monthly) resolution of the river flow time series, all of the indices show distinct changes over six decades and clearly correspond to the timing as well as the impacts of dam closure on the flow regime of the Mijares River. Reductions in average, high and low flows are all clearly identified, giving confidence that the key changes have been recognized, even if changes in large flood events, which are so crucial to riparian disturbance, are not quantified. Furthermore, the clearest changes occur after 1976, corresponding with the closure of the Arenós dam, with some smaller changes evident in some indices during the 1968-1976 period, particularly in relation to inter-month and inter-annual flow variation and corresponding with the early operation of the Vallat dam.

More innovatively, the vector and raster-based analyses of riparian zone land cover provide information that goes far beyond a simple description of stabilization and terrestrialization of the riparian zone. The analysis (Table 6) of changes in land cover patch density/number, size, edge length, shape and diversity provides a wealth of information from which the detailed dynamics of riparian adjustment to flow regime can be described and processes of adjustment can be inferred. Furthermore, the quality of the analysis of land cover is confirmed by the transect based ground data, giving confidence in the outcomes of the analysis of landscape metrics.

Although in some cases subtle, the landscape metrics illustrate trends through the study period in patch number, size, shape and diversity and also in the relative number of patches under different cover types. Moreover, the most marked changes occur between the 1976 and 1997 images and so correspond with the closure of the Arenós dam.

The combined use of fuzzy sets theory and a confusion matrix allowed the precise analysis of similarities between periods. Because vegetation often forms a mosaic, the classification of vegetation or land cover units into only one class is often difficult or erroneous (Muller et al., 1998). Adopting a method for accuracy assessment based on the fuzzy set theory is particularly useful when comparing maps obtained by photo interpretation of geocorrected images, where some level of positional tolerance can be assumed (Power et al., 2001; Foody, 2002; Wealands et al., 2005) and also because adjacent categories have vague transitions in nature (Foody, 1996). A further benefit of using fuzzy sets theory is that it provides additional tools for analysing map similarity (Muller et al., 1998). The fuzzy kappa gives more relevance to the spatiotemporal distribution of the landscape mosaic than other statistics because it is not based on a cell-by-cell comparison and it can capture qualitative similarities between two maps (Power et al., 2001) because the categories of neighbouring cells are taken into account (Hagen, 2003; Hagen-Zanker et al., 2005).

\section{Interpreting the observed riparian dynamics}

In general, our analysis reveals that there has been an increase in the cover and density of woody vegetation and a synchronous reduction in the complexity of the riparian corridor of the middle reaches of the Mijares River, which have accompanied a decrease in the magnitude and variability of river flows over the last 60 years (Figure 2). This adjustment has corresponded with a change from an essentially natural flow regime, which included occasional very large floods, prior to the hydropower developments in the 1960s and 1970s, to the current highly regulated regime.

In the 1956 image, the riparian corridor reflects the pre-hydropower, essentially unregulated flow regime. Land cover is varied, with the most even distribution of cover across the various classes amongst the analysed images and the most extensive area of cultivated land (Figure 4). The latter probably reflects the peak of agricultural intensity prior to rural depopulation in this part of the catchment and thus represents a human modification of the riparian zone at that time.

Between the 1956 and 1976 images (Figure 3), not only was there an implementation of the hydropower scheme, with the closure of the largest dam immediately prior to the 1976 image, but the riparian zone would also have been impacted by two very large floods in 1957 and 1967. Because these floods occurred at a time of rural depopulation, they may have been sufficient to drive cultivated land use out of the riparian corridor, 
accounting for the marked decrease in cultivated land cover by 1976 (Figure 4). In addition, the 1967 flood combined with the closure of the Arenós dam and the imposition of heavy flow regulation immediately before the date of the 1976 image explains the major increase in bare sediment land cover by 1976 (Figures 3 and 4). Indeed, the major transitions between land cover types were from water, herbs and cultivated land to bare sediment, with sizeable transitions from dense woody vegetation to bare sediment (Table 7). A major reduction in dense woody vegetation and an expansion in herbs and sparse woody vegetation between 1956 and 1976 (Figure 4) may also indicate the response of the riparian zone to large flood disturbances. However, the effects of these possible controlling mechanisms cannot be separated. They have combined to induce the land cover change between 1956 and 1976, which shows an increase in the number of land cover patches in virtually all land cover types (Table 5), a decrease in patch size, an increase in size variability and an increase in patch edge length between 1956 and 1976 (Table 6). Furthermore, the increased area of bare sediment and water land cover by 1976 appears to have provided the space for pioneer species to colonize, as evidenced by the large representation of riparian trees that are less than 30 years old located on these 1976 land cover types within the 2007 surveyed transects, particularly P. nigra, S. eleagnos and Tamarix spp. (Figure 7).

Between 1976 and 1997, the river flow regime was heavily regulated, and this appears to have allowed colonization of bare sediment and herb-covered areas within the riparian zone by woody vegetation and also the transition of much sparse woody cover to dense woody cover (Table 7). These transitions were accompanied by considerable simplification of the riparian vegetation structure, with a dramatic reduction in the number of land cover patches and the complexity of their shape, an increase in patch size and the domination of the riparian area by dense woody vegetation (Tables 5 and 6, Figure 4). This change in riparian cover and structure was accompanied by vegetation encroachment of the 1976 active river channel margins (Figure 3), a very major reduction in river channel width (Figure 5) and the appearance of some new species that were dated as less than 20 years old during the 2007 field survey, notably $N$. oleander, S. eleagnos and C. myrtifolia (Figure 7).

Between 1997 and 2007, the river flow regime continued to be heavily regulated, and the riparian vegetation structure continued to simplify, with the virtual disappearance of bare sediment cover and a further dramatic reduction of herb and sparse woody vegetation cover at the expense of dense woody vegetation cover (Figure 4). The 2007 field survey shows that within the dense woody vegetation patches, riparian tree species are confined to the active river channel margins with terrestrial woody species dominating the rest of the riparian corridor (Figure 7). The 2007 image shows a further reduction in the number of riparian patches (Table 5), a further increase in patch size and a reduction in patch shape complexity (Table 6). Although the structure of the riparian corridor vegetation continued to adjust during this period, active river channel narrowing stabilized and even showed a slight widening in comparison with that in the 1997 image.

These observations show some similar trends to other studies. For example, Schmidt et al. (1995) found that changes were particularly noticeable in the first two decades after damming along the Snake River, USA. Harris et al. (1987) noted that after water diversion, the changes in the herb stratum tend to be the most pronounced, and Azami et al. (2004) observed that the reduced flood peaks below a dam led to the expansion of riparian forest area and its transition into later successional stages. Similar shifts were detected along the Green River, USA, by Merritt and Cooper (2000), 37 years after dam construction, indicating the eventual replacement of Populus-dominated riparian forest by drought-tolerant desertic shrubs and the enlargement of in-channel fluvial marshes. Similarly, many Mediterranean rivers have experienced a loss of riparian woodland, but few studies have attempted to spatially quantify that loss and its historical timing (Muller et al., 2002). In the middle Ebro River, Spain, pioneer forests doubled their spatial extent after the intensification of the river regulation in the 1950s, but currently, they are characterized by declining, sparse stands of $P$. nigra-Salix alba-Tamarix spp., probably as a result of the increase in the frequency and duration of low water events (Ollero, 2010); and late-seral species are more frequent because their regeneration is not so dependent on recurrent fluvio-geomorphic events (González et al., 2010). On the Mijares River, our observations suggest that encroachment of dense woody vegetation across the riparian corridor is almost complete within 40 years of major dam closure and is associated with the persistent lowflow conditions and low-flow variability. These same factors have been identified as contributors to woodland expansion and encroachment in other rivers (e.g. Johnson, 1994; Huxman et al., 2005; Santos, 2010; Magdaleno and Fernández, 2011). However, the composition of the vegetation within the Mijares riparian corridor appears to still be adjusting to some extent and is likely to take considerably longer to stabilize than our 60-year study period. This timescale conforms to that proposed by González et al. (2010) for the Ebro River, where the effects of regulation on vegetation structure are still not complete after 50 
years. Indeed, in this context, Johnson (1992) suggested that almost two centuries would be required for riparian vegetation to reach a new post-dam steady state along the Missouri River. He attributed this to the longevity of Populus and Salix trees established before the regulation and their slow replacement by later successional species (Johnson, 1997). Although the Populus and Salix species observed along the Mijares River may be shorter lived than those along the Missouri River, they may be expected to survive for many more decades now that river channels dynamics are negligible, although they could decline rapidly depending on natural processes, such as the arrival of pathogens (Bastien et al., 2009; González et al., 2010) and invasive species, vertical bank erosions (Groeneveld and Griepentrog, 1985) and fires as well as humaninduced processes, e.g. streambed mining and groundwater pumping.

Another aspect of the changes observed in riparian vegetation is the increase in non-native species at the study sites. There is a particular concern about the invasive cane or giant reed A. donax L. (Sanz Elorza et al., 2004), declared by the International Union for Conservation of Nature as one of the most dangerous and harmful invasive alien plants worldwide (Bañares et al., 2004). A similar invasion phenomenon has been observed in numerous studies where reduced recruitment of native riparian plants has followed severe flow regulation (Rood and Mahoney, 1990) and has been accompanied by the spread of non-native species (Johnson et al., 1995; Merritt and Cooper, 2000; Stromberg, 2001; Shafroth et al., 2002; Uowolo et al., 2005; Richardson et al., 2007).

\section{Implications for management}

Natural disturbances (such as fire and a flashy hydrological regime, typical of Mediterranean rivers), as well as site specific human disturbances, control the structure of riparian vegetation (McIntyre and Hobbs, 1999; Johnson, 2000; Hughes et al., 2001; Cooper et al., 2006; Greet et al., 2011). The life cycle of riparian woody vegetation depends on seasonal changes in water levels and extreme flow disturbances (Karrenberg et al., 2002). If these changes are no longer present, the life cycle is interrupted, and riparian tree recruitment ceases or is dramatically reduced (Mahoney and Rood, 1998; Braatne et al., 2007). In particular, reduced flow disturbances lead to a reduction in the turnover of riparian habitats and thus reduced availability of moist bare sediment habitat for seed germination and also an increase in hydric stress on established riparian trees located far from the channel margins (Harris et al., 1987; Scott et al., 1996; Auble and Scott, 1998; Kranjcec et al., 1998; Nakamura and Shin, 2001). Furthermore, the changing vegetation structure can have important feedbacks, influencing future susceptibility of the riparian zone to disturbance (Shafroth et al., 2002). For all of these reasons, flow regulation leads to a narrowing and ageing of the river margin riparian woodland and an encroachment of terrestrial species as has been observed along other semi-arid rivers (Huxman et al., 2005; Santos, 2010).

Sustainable management of riparian ecosystems along regulated rivers requires the reinstatement of some of the natural elements of the flow regime (Richter and Richter, 2000; Hughes and Rood, 2003; Lite and Stromberg, 2005; Rood et al., 2005; Merritt et al., 2010). Furthermore, if river margin woodland is well established, even the reinstatement of significant high-flow events may not be sufficient to achieve riparian habitat turnover, and so some initial woodland management may be necessary.

In the case of Mijares River, the upper and middle course has been designated a site of community importance for its natural values because of the importance of the riparian habitats (Natura 2000 Networking Programme), but from our observations, these habitats are threatened if elements of the natural dynamism of the river are not restored. Thus, future dam management needs to respond to the expansion of the downstream riparian forest and its encroachment by terrestrial species, with the introduction of more natural disturbance elements into the flow regime. In addition, riparian changes have progressed sufficiently far for some tree felling as well as control of invading exotic species (e.g. A. donax) to be necessary, if the revised flow regime is to achieve rapid benefits for the riparian ecosystem.

\section{ACKNOWLEDGEMENTS}

The authors are grateful to Paula De Lamo (who worked in an early version of this study), Carlos GonzálezHidalgo (who gave us access to the MOPREDAS database) and Alicia García-Arias and Óscar Belmar (for their support in the calculation of confusion matrices and in the flow regime analysis, respectively). We also thank Confederación Hidrográfica del Júcar (Spanish Ministry of Agriculture, Food and Environment) and the professors Juan Marco Segura and Javier Paredes for the hydrological data provided to develop this study. TECNOMA S.A. provided logistic support. Finally, we acknowledge the Universitat Politècnica de 
València for the two grants of the Support Programme for Research and Development 'Programa de Apoyo a la Investigación y Desarrollo' (PAID 00-10 and 00-11). This study was partially funded by the Spanish Ministry of Economy and Competitiveness with the projects 'Recent environmental changes in fluvial systems: morphological and sedimentological consequences' (CGL2009-14220-C02- 02-BTE) and SCARCE (Consolider-Ingenio 2010 CSD2009- 00065). The feedback of two anonymous reviewers has been very helpful and is greatly appreciated.

\section{REFERENCES}

Aguiar F, Fernandes MR, Ferreira MT. 2010. Riparian vegetation metrics as tools for guiding ecological restoration in riverscapes. Proceedings $7^{\text {th }}$ European Conference on Ecological Restoration, 23-27 August 2010, Avignon, France, p. 4.

Aguiar F, Ferreira MT. 2005. Human-disturbed landscapes: effects on composition and integrity of riparian woody vegetation in the Tagus River basin, Portugal. Environmental Conservation 32(01): 30-41. DOI: doi:10.1017/S0376892905001992.

Aguilella A, Engelbrecht M, Mallach M, Riera J. 2007. Bases para un plan de conservación de riberas de la Confederación Hidrográfica del Júcar. Memoria final. Trabajo realizado por la Universidad de Valencia para la Confederación Hidrográfica del Júcar: Valencia, pp. 175.

Aguilella A, Riera J, Gómez-Serrano M, Mayoral O, Moreyra E. 2005. Evaluación del estado ecológico de los ríos de la cuenca hidrográfica del Júcar mediante el uso del índice QBR. Memoria final. Trabajo realizado por el Jardí Botànic de la Universitat de València para la Confederación Hidrográfica del Júcar: Valencia, pp. 258.

Apan AA, Raine SR, Paterson MS. 2002. Mapping and analysis of changes in the riparian landscape structure of the Lockyer Valley Catchment, Queensland, Australia. Landscape and Urban Planning 59(1): 43-57. DOI: 10.1016/S0169-2046(01)00246-8.

Apan AA, Raine SS, Paterson MS. 2000. Quantifying landscape fragmentation in the Lockyer Valley Catchment, Queensland: 1973 - 1997. AURISA 2000 - The $28^{\text {th }}$ Annual Conference of AURISA QLD, Hyatt Coolum Resort, Coolum, p. 10.

Auble GT, Scott ML. 1998. Fluvial disturbance patches and cottonwood recruitment along the upper Missouri River, Montana. Wetlands 18(4): 546-556. DOI: 10.1007/BF03161671.

Azami K, Suzuki H, Toki S. 2004. Changes in riparian vegetation communities below a large dam in a monsoonal region: Futase Dam, Japan. River Research and Applications 20(5): 549-563. DOI: 10.1002/rra.763.

Bañares Â, Blanca G, Güemes J, Moreno JC, Ortiz S. 2004. Atlas y libro rojo de la flora vascular amenazada de España. Dirección General de Conservación de la Naturaleza: Madrid.

Bastien C, Chenault N, Dowkiw A, Villar M, Klein É, Frey P. 2009. Interactions between natural and cultivated populations: the example of poplar. Biofutur 305: 31-34.

Batalla RJ, Gómez CM, Kondolf GM. 2004. Reservoir-induced hydrological changes in the Ebro River basin (NE Spain). Journal of Hydrology 290(1-2): 117-136. DOI: 10.1016/j.jhydrol.2003.12.002.

Belmar O, Velasco J, Martinez-Capel F. 2011. Hydrological classification of natural flow regimes to support environmental flow assessments in intensively regulated Mediterranean rivers, Segura River basin (Spain). Environmental Management 47(5): 992-1004. DOI: 10.1007/s00267-011-9661-0.

Benjankar R, Egger G, Jorde K, Goodwin P, Glenn NF. 2011. Dynamic floodplain vegetacion model development for the Kootenai River, USA. Journal of Environmental Management 92: 3058-3070. DOI: 10.1016/j.jenvman.2011.07.017.

Benjankar R, Jorde K, Yager EM, Egger G, Goodwin P, Glenn NF. 2012. The impact of river modification and dam operation on floodplain vegetation succession trends in the Kootenai River, USA. Ecological Engineering 46: 88-97. DOI: 10.1016/j.ecoleng.2012.05.002.

Bertoldi W, Drake NA, Gurnell AM. 2011a. Interactions between river flows and colonizing vegetation on a braided river: exploring spatial and temporal dynamics in riparian vegetation cover using satellite data. Earth Surface Processes and Landforms 36(11): 1474-1486. DOI: 10.1002/esp.2166.

Bertoldi W, Gurnell AM, Drake NA. 2011b. The topographic signature of vegetation development along a braided river: Results of a combined analysis of airborne lidar, color air photographs, and ground measurements. Water Resources Research 47(6): W06525. DOI: 10.1029/2010wr010319.

Blondel J, Aronson J. 1999. Biology and wildlife of the Mediterranean region. Oxford University Press: New York.

Braatne JH, Jamieson R, Gill KM, Rood SB. 2007. Instream flows and the decline of riparian cottonwoods along the Yakima River, Washington, USA. River Research and Applications 23(3): 247-267. DOI: 10.1002/rra.978.

Braatne JH, Rood SB, Goater LA, Blair CL. 2008. Analyzing the impacts of dams on riparian ecosystems: a review of research strategies and their relevance to the Snake River through Hells Canyon. Environmental Management 41: 267-281. DOI: 10.1007/s00267-007-9048-4.

Busch DE, Smith SD. 1995. Mechanisms associated with decline of woody species in riparian ecosystems of the Southwestern U.S. Ecological Monographs 65(3): 347-370. DOI: 10.2307/2937064. 
Cohen J. 1960. A coefficient of agreement for nominal scales. Educational and psychological measurement 20(1): 37 46. DOI: $10.1177 / 001316446002000104$.

Cooper DJ, Dickens J, Hobbs NT, Christensen L, Landrum L. 2006. Hydrologic, geomorphic and climatic processes controlling willow establishment in a montane ecosystem. Hydrological Processes 20(8): 1845-1864. DOI: 10.1002/hyp.5965.

Crawford PHC, Hoagland BW. 2009. Can herbarium records be used to map alien species invasion and native species expansion over the past 100 years? Journal of Biogeography 36(4): 651-661. DOI: 10.1111/j.13652699.2008.02043.x.

CHJ. 2005. Estudio hidráulico del río Mijares (Anexo 4). In: Normas de explotación de la presa de Arenós. Tomos 2. Apéndices. Confederación Hidográfica del Júcar. Ministerio de Medio Ambiente: Valencia.

CHJ. 2009. Esquema provisional de temas importantes. Anexo B - Fichas de temas importantes. Confederación Hidrográfica del Júcar: Valencia. Available online at: http://www.phjucar.com/docs/cons_publica/iniciales/Fichas01020306_EdB.pdf, pp. 208.

Dixon MD, Johnson WC. 1999. Riparian vegetation along the middle Snake River, Idaho: Zonation, geographical trends and historical changes. Great Basin Naturalist 59(1): 18-34.

Dynesius M, Nilsson C. 1994. Fragmentation and flow regulation of river systems in the northern third of the world. Science 266(5186): 753-762. DOI: 10.1126/science.266.5186.753.

Egger G, Politti E, Woo H, Cho K-H, Park M, Cho H, Benjankar R, Lee N-J, Lee H. 2012. Dynamic vegetation model as a tool for ecological impact assessments of dam operation. Journal of Hydro-environment Research 6(2): 151161. DOI: 10.1016/j.jher.2012.01.007.

Fernandes MR, Aguiar FC, Ferreira MT. 2011. Assessing riparian vegetation structure and the influence of land use using landscape metrics and geostatistical tools. Landscape and Urban Planning 99(2): 166-177. DOI: 10.1016/j.landurbplan.2010.11.001.

Foody GM. 1996. Fuzzy modelling of vegetation from remotely sensed imagery. Ecological Modelling 85(1): 3-12. DOI: 10.1016/0304-3800(95)00012-7.

Foody GM. 2002. Status of land cover classification accuracy assessment. Remote Sensing of Environment 80(1): 185201. DOI: 10.1016/s0034-4257(01)00295-4.

Friedman JM, Osterkamp WR, L. SM, Auble GT. 1998. Downstream effects of dams on channel geometry and bottomland vegetation: regional patterns in the Great Plains. Wetlands 18(4): 619-633. DOI: 10.1007/BF03161677.

Garófano-Gómez V, Martínez-Capel F, Nebot T, Mondéjar N, Cavallé A, Morillo R. 2008. Riparian species and flow regime: ecological studies for application in environmental flow assessments and river restoration (Mijares River, Spain). In: Gumiero B, Rinaldi M,Fokkens B (Eds.), IV ${ }^{\text {th }}$ ECRR International Conference on River Restoration, S. Servolo Island, Venice, Italy, pp. 769-778.

Garófano-Gómez V, Martínez-Capel F, Peredo-Parada M, Olaya Marín EJ, Muñoz Más R, Soares Costa RM, PinarArenas JL. 2011. Assessing hydromorphological and floristic patterns along a regulated Mediterranean River: The Serpis River (Spain). Limnetica 30(2): 307-328.

González-Hidalgo JC, Brunetti M, de Luis M. 2011. A new tool for monthly precipitation analysis in Spain: MOPREDAS database (monthly precipitation trends December 1945-November 2005). International Journal of Climatology 31(5): 715-731. DOI: 10.1002/joc.2115.

González del Tánago M, García de Jalón D. 2011. Riparian Quality Index (RQI): A methodology for characterizing and assessing environmental conditions of riparian zones. Limnetica 30(2): 235-254.

González E, González-Sanchis M, Cabezas Á, Comín F, Muller E. 2010. Recent changes in the riparian forest of a large regulated Mediterranean river: Implications for management. Environmental Management 45(4): 669-681. DOI: 10.1007/s00267-010-9441-2.

González E, González-Sanchis M, Comín FA, Muller E. 2012. Hydrologic thresholds for riparian forest conservation in a regulated large Mediterranean river. River Research and Applications 28(1): 71-80. DOI: 10.1002/rra.1436.

Greet JOE, Webb AJ, Cousens RD. 2011. The importance of seasonal flow timing for riparian vegetation dynamics: a systematic review using causal criteria analysis. Freshwater Biology 56(7): 1231-1247. DOI: 10.1111/j.13652427.2011.02564.x.

Gregory SV, Swanson FJ, McKee WA, Cummins KW. 1991. An ecosystem perspective of riparian zones. Bioscience 41(8): 540-551.

Groeneveld DP, Griepentrog TE. 1985. Interdependence of groundwater, riparian vegetation, and streambank stability: A case study. Symposium on Riparian Ecosystems and Their Management, Tucson, Arizona pp. 44-48.

Hagen-Zanker A, Straatman B, Uljee I. 2005. Further developments of a fuzzy set map comparison approach. International Journal of Geographical Information Science 19: 769-785. DOI: 10.1080/13658810500072137.

Hagen A. 2002. Multi-method assessment of map similarity. In: Ruiz M, Gould M,Ramon J (Eds.), Proceedings of the Fifth AGILE Conference on Geographic Information Science, Palma (Mallorca), Spain, p. 8.

Hagen A. 2003. Fuzzy set approach to assessing similarity of categorical maps. International Journal of Geographical Information Science 17(3): 235-249. DOI: 10.1080/13658810210157822.

Harris RR, Fox CA, Risser R. 1987. Impacts of hydroelectric development on riparian vegetation in the Sierra Nevada region, California, USA. Environmental Management 11(4): 519-527. DOI: 10.1007/BF01867659. 
Hohensinner S, Jungwirth M, Muhar S, Schmutz S. 2011. Spatio-temporal habitat dynamics in a changing Danube River landscape 1812-2006. River Research and Applications 27(8): 939-955. DOI: 10.1002/rra.1407.

Hooke JM. 2006. Human impacts on fluvial systems in the Mediterranean region. Geomorphology 79(3-4): 311-335. DOI: 10.1016/j.geomorph.2006.06.036.

Howe WH, Knopf FL. 1991. On the imminent decline of Rio Grande cottonwoods in central New Mexico. The Southwestern Naturalist 36(2): 218-224.

Hughes FMR, Adams WM, Muller E, Nilsson C, Richards KS, Barsoum N, Decamps H, Foussadier R, Girel J, Guilloy H, Hayes A, Johansson M, Lambs L, Pautou G, Peiry JL, Perrow M, Vautier F, Winfield M. 2001. The importance of different scale processes for the restoration of floodplain woodlands. Regulated Rivers: Research \& Management 17(4-5): 325-345. DOI: 10.1002/rrr.656.

Hughes FMR, Rood SB. 2003. Allocation of river flows for restoration of floodplain forest ecosystems: A review of approaches and their applicability in Europe. Environmental Management 32(1): 12-33. DOI: 10.1007/s00267003-2834-8.

Huxman TE, Wilcox BP, Breshears DD, Scott RL, Snyder KA, Small EE, Hultine K, Pockman WT, Jackson RB. 2005. Ecohydrological implications of woody plant encroachment. Ecology 86(2): 308-319. DOI: 10.1890/03-0583.

Johnson WC. 1992. Dams and riparian forests: case study from the Upper Missouri River. Rivers 3(4): 229-242.

Johnson WC. 1994. Woodland expansions in the Platte River, Nebraska: Patterns and causes. Ecological Monographs 64(1): 45-84. DOI: $10.2307 / 2937055$.

Johnson WC. 1997. Equilibrium response of riparian vegetation to flow regulation in the Platte river, Nebraska. Regulated Rivers: Research \& Management 13(5): 403-415. DOI: 10.1002/(SICI)10991646(199709/10)13:5<403::AID-RRR465>3.0.CO;2-U.

Johnson WC. 1998. Adjustment of riparian vegetation to river regulation in the Great Plains, USA. Wetlands 18(4): 608-618. DOI: 10.1007/BF03161676.

Johnson WC. 2000. Tree recruitment and survival in rivers: infuence of hydrological processes. Hydrological Processes 14: 3051-3074. DOI: 10.1002/1099-1085(200011/12)14:16/17<3051::AID-HYP134>3.0.CO;2-1.

Johnson WC, Dixon MD, Simons R, Jenson S, Larson K. 1995. Mapping the response of riparian vegetation to possible flow reductions in the Snake River, Idaho. Geomorphology 13(1-4): 159-173. DOI: 10.1016/0169$555 x(95) 00048-a$.

Karrenberg S, Edwards PJ, Kollmann J. 2002. The life history of Salicaceae living in the active zone of floodplains. Freshwater Biology 47(4): 733-748. DOI: 10.1046/j.1365-2427.2002.00894.x.

Katz GL, Friedman JM, Beatty SW. 2005. Delayed effects of flood control on a flood-dependent riparian forest. Ecological Applications 15(3): 1019-1035. DOI: 10.1890/04-0076.

Kondolf GM, Batalla RJ. 2005. Hydrological effects of dams and water diversions on rivers of Mediterranean-climate regions: Examples from California. In: Garcia C,Batalla RJ (Eds.), Catchment dynamics and river processes: Mediterranean and other climate regions. Elsevier Publishers Limited: London, pp. 197-211.

Kondolf GM, Larson M. 1995. Historical channel analysis and its application to riparian and aquatic habitat restoration. Aquatic Conservation: Marine and Freshwater Ecosystems 5(2): 109-126. DOI: 10.1002/aqc.3270050204.

Kranjcec J, Mahoney JM, Rood SB. 1998. The responses of three riparian cottonwood species to water table decline. Forest Ecology and Management 110(1-3): 77-87. DOI: 10.1016/s0378-1127(98)00276-x.

Lite SJ, Stromberg JC. 2005. Surface water and ground-water thresholds for maintaining Populus-Salix forests, San Pedro River, Arizona. Biological Conservation 125(2): 153-167. DOI: 10.1016/j.biocon.2005.01.020.

Magdaleno F, Fernández JA. 2011. Hydromorphological alteration of a large Mediterranean river: Relative role of high and low flows on the evolution of riparian forests and channel morphology. River Research and Applications 27(3): 374-387. DOI: 10.1002/rra.1368.

Mahoney JM, Rood SB. 1998. Streamflow requirements for cottonwood seedling recruitment - An integrative model. Wetlands 18(4): 634-645. DOI: 10.1007/BF03161678.

Mathews R, Richter BD. 2007. Application of the indicators of hydrologic alteration software in environmental flow setting. JAWRA Journal of the American Water Resources Association 43(6): 1400-1413. DOI: 10.1111/j.17521688.2007.00099.x.

McGarigal K, Marks BJ. 1994. Fragstats. Spatial pattern analysis program for quantifying landscape structure. Corvallis, OR, pp. 141.

McGarigal K, Marks BJ. 1995. Fragstats: Spatial analysis program for quantifying landscape structure. USDA Forest Service General Technical Report PNW-GTR-35.

McIntyre S, Hobbs R. 1999. A Framework for conceptualizing human effects on landscapes and its relevance to management and research models. Conservation Biology 13(6): 1282-1292. DOI: 10.1046/j.15231739.1999.97509.x.

Merritt DM, Cooper DJ. 2000. Riparian vegetation and channel change response to river regulation: A comparative study of regulated and unregulated streams in the Green River Basin, USA. Regulated River Research and Management 16: 543-564. DOI: 10.1002/1099-1646(200011/12)16:6<543::AID-RRR590>3.0.CO;2-N.

Merritt DM, Scott ML, LeRoy Poff N, Auble GT, Lytle DA. 2010. Theory, methods and tools for determining environmental flows for riparian vegetation: riparian vegetation-flow response guilds. Freshwater Biology 55(1): 206-225. DOI: 10.1111/j.1365-2427.2009.02206.x. 
Monk WA, Wood PJ, Hannah DM, Wilson DA. 2007. Selection of river flow indices for the assessment of hydroecological change. River Research and Applications 23(1): 113-122. DOI: 10.1002/rra.964.

Muller E, Guilloy-Froget H, Barsoum N, Brocheton L. 2002. Populus nigra L. in the Garonne valley: legacy of the past and present constraints. C. R. Biologies 325: 1129-1141. DOI: 10.1016/S1631-0691(02)01519-6.

Muller SV, Walker DA, Nelson FE, Auerbach NA, Bockheim JG, Guyer S, Sherba D. 1998. Accuracy assessment of a land-cover map of the Kuparuk river basin, Alaska: considerations for remote regions. Photogrammetric Engineering and Remote Sensing 64(6): 619-658.

Munné A, Prat N, Solá C, Bonada N, Rieradevall M. 2003. A simple field method for assessing the ecological quality of riparian habitat in rivers and streams: QBR index. Aquatic Conservation: Marine and Freshwater Ecosystems 13: 147-163. DOI: $10.1002 /$ aqc.529.

Naiman RJ, Décamps H, McClain ME. 2005. Riparia - Ecology, conservation and management of streamside communities. Elsevier Academic Press.

Naiman RJ, Décamps H, Pollock M. 1993. The role of riparian corridors in maintaining regional biodiversity. Ecological Applications 3(2): 209-212. DOI: 10.2307/1941822.

Naiman RJ, Latterell JJ, Pettit NE, Olden JD. 2008. Flow variability and the biophysical vitality of river systems. Comptes Rendus Geoscience 340(9-10): 629-643. DOI: 10.1016/j.crte.2008.01.002.

Nakamura F, Shin N. 2001. The downstream effects of dams on the regeneration of riparian tree species in northern Japan. In: Dorava JM, Montgomery DR, Palcsak BB,Fitzpatrick FA (Eds.), Geomorphic Processes and Riverine Habitat Water Science and Application 4. American Geophysical Union: San Francisco, Calif, pp. 173-181.

New T, Xie Z. 2008. Impacts of large dams on riparian vegetation: applying global experience to the case of China's Three Gorges Dam. Biodiversity and Conservation 17(13): 3149-3163. DOI: 10.1007/s10531-008-9416-2.

Olden JD, Poff NL. 2003. Redundancy and the choice of hydrologic indices for characterizing streamflow regimes. River Research and Applications 19(2): 101-121. DOI: 10.1002/rra.700.

Ollero A. 2007. Territorio fluvial. Diagnóstico y propuesta para la gestión ambiental y de riesgos en el Ebro y los cursos bajos de sus afluentes. Bakeaz \& Fundación Nueva Cultura del Agua: Bilbao.

Ollero A. 2010. Channel changes and floodplain management in the meandering middle Ebro River, Spain. Geomorphology 117(3-4): 247-260. DOI: 10.1016/j.geomorph.2009.01.015.

Paredes-Arquiola J, Martinez-Capel F, Solera A, Aguilella V. 2011. Implementing environmental flows in complex water resources systems - case study: The Duero river basin, Spain. River Research and Applications: n/a-n/a. DOI: $10.1002 /$ rra.1617.

Paredes-Arquiola J, Solera-Solera A, Andreu-Álvarez J. 2008. Reglas de operación para sistemas multiembalse, combinando métodos heurísticos y redes de flujo. Ingeniería Hidráulica en México 23(3): 151-164.

Patten D. 1998. Riparian ecosytems of semi-arid North America: Diversity and human impacts. Wetlands 18(4): 498512. DOI: $10.1007 / \mathrm{bf03} 161668$.

Pérez-Martín MA. 2005. Modelo distribuido de simulación del ciclo hidrológico y calidad del agua, integrado en sistemas de información geográfica, para grandes cuencas. Aportación al análisis de presiones e impactos de la Directiva Marco del Agua. Universidad Politécnica de Valencia, Valencia, Spain.

Petts GE, Gurnell AM. 2005. Dams and geomorphology: Research progress and future directions. Geomorphology 71(1-2): 27-47. DOI: 10.1016/j.geomorph.2004.02.015.

Petts GE, Gurnell AM. 2012. Hydrogeomorphic effects of water resources developments. Treatise in Geomorphology, Volume 13: Geomorphology of Human Disturbances, Hazards and Climate Change, Chapter 8. Elsevier.

Power C, Simms A, White R. 2001. Hierarchical fuzzy pattern matching for the regional comparison of land use maps. International Journal of Geographical Information Science 15(1): 77-100. DOI: 10.1080/136588100750058715.

Quereda J, Montón E, Escrig J. 2004. El déficit hídrico en la Cuenca del Mijares. In: Gil Olcina A (Ed.), Alteración de los regímenes fluviales peninsulares. Fundación Caja Murcia: Murcia, pp. 303-328.

Richardson DM, Holmes PM, Esler KJ, Galatowitsch SM, Stromberg JC, Kirkman SP, Pysek P, Hobbs RJ. 2007. Riparian vegetation: degradation, alien plant invasions, and restoration prospects. Diversity \& Distributions 13(1): 126-139. DOI: 10.1111/j.1366-9516.2006.00314.x.

Richter BD, Davis MM, Apse C, Konrad C. 2012. A presumptive standard for environmental flow protection. River Research and Applications 28: 1312-1321. DOI: 10.1002/rra.1511.

Richter BD, Richter HE. 2000. Prescribing flood regimes to sustain riparian ecosystems along meandering rivers. Conservation Biology 14(5): 1467-1478. DOI: 10.1046/j.1523-1739.2000.98488.x.

Rood SB, Gourley CR, Ammon EM, Heki LG, Klotz JR, Morrision ML, Mosley D, Scoppettone GG, Swanson S, Wagner PL. 2003. Flows for floodplain forests: A successful riparian restoration. Bioscience 53(7): 647-656. DOI: 10.1641/0006-3568(2003)053[0647:FFFFAS]2.0.CO;2.

Rood SB, Mahoney JM. 1990. Collapse of riparian poplar forests downstream from dams in western prairies: Probable causes and prospects for mitigation. Environmental Management 14(4): 451-464. DOI: 10.1007/BF02394134.

Rood SB, Samuelson GM, Braatne JH, Gourley CR, Hughes FMR, Mahoney JM. 2005. Managing river flows to restore floodplain forests. Frontiers in Ecology and the Environment 3(4): 193-201. DOI: 10.1890/15409295(2005)003[0193:MRFTRF]2.0.CO;2.

Saaty TL. 1980. The analytic hierarchy process: planning, priority setting, resource allocation. McGraw-Hill: New York. 
Salinas MJ, Blanca G, Romero AT. 2000. Evaluating riparian vegetation in semi-arid Mediterranean watercourses in the south-eastern Iberian Peninsula. Environmental Conservation 27(01): 24-35.

Santos MJ. 2010. Encroachment of upland Mediterranean plant species in riparian ecosystems of southern Portugal. Biodiversity and Conservation 19(9): 2667-2684. DOI: 10.1007/s10531-010-9866-1.

Sanz Elorza M, Dana Sánchez ED, Sobrino Vesperinas E. 2004. Atlas de las plantas alóctonas invasoras de España. Dirección General para la Biodiversidad: Madrid.

Scott ML, Friedman JM, Auble GT. 1996. Fluvial process and the establishment of bottomland trees. Geomorphology 14(4): 327-339. DOI: 10.1016/0169-555x(95)00046-8.

Schmidt JC, Grams PE, Webb RH. 1995. Comparison of the magnitude of erosion along two large regulated rivers. JAWRA Journal of the American Water Resources Association 31(4): 617-631. DOI: 10.1111/j.17521688.1995.tb03389.x.

Schuft MJ, Moser TJ, Wigington PJ, Stevens DL, McAllister LS, Chapman SS, Ernst TL. 1999. Development of landscape metrics for characterizing riparian-stream networks. Photogrammetric Engineering and Remote Sensing 65: 1157-1167.

Shafroth PB, Stromberg JC, Patten DT. 2002. Riparian vegetation response to altered disturbance and stress regimes. Ecological Applications 12: 107-123. DOI: 10.1890/1051-0761(2002)012[0107:RVRTAD]2.0.CO;2.

Stromberg J. 2001. Restoration of riparian vegetation in the south-western United States: importance of flow regimes and fluvial dynamism. Journal of Arid Environments 49(1): 17-34. DOI: 10.1006/jare.2001.0833.

Stromberg JC, Tiller R, Richter B. 1996. Effects of groundwater decline on riparian vegetation of semiarid regions: The San Pedro, Arizona. Ecological Applications 6(1): 113-131. DOI: 10.2307/2269558.

Takahashi M, Nakamura F. 2011. Impacts of dam-regulated flows on channel morphology and riparian vegetation: a longitudinal analysis of Satsunai River, Japan. Landscape and Ecological Engineering 7(1): 65-77. DOI: 10.1007/s11355-010-0114-3.

Uowolo AL, Binkley D, Carol Adair E. 2005. Plant diversity in riparian forests in northwest Colorado: Effects of time and river regulation. Forest Ecology and Management 218(1-3): 107-114. DOI: 10.1016/j.foreco.2005.07.003.

van Vliet J, Hagen-Zanker A, Hurkens J, Vanhout R. 2010. Map Comparison Kit 3. User Manual. Research Institute for Knowledge Systems (RIKS BV): Maastricht, The Netherlands.

Visser H, de Nijs T. 2006. The Map Comparison Kit. Environmental Modelling \& Software 21(3): 346-358. DOI: 10.1016/j.envsoft.2004.11.013.

Wealands SR, Grayson RB, Walker JP. 2005. Quantitative comparison of spatial fields for hydrological model assessment - some promising approaches. Advances in Water Resources 28(1): 15-32. DOI: 10.1016/j.advwatres.2004.10.001.

Williams CA, Cooper DJ. 2005. Mechanisms of riparian cottonwood decline along regulated rivers. Ecosystems 8(4): 382-395. DOI: 10.1007/s10021-003-0072-9. 